$2-2013$

\title{
Transient Receptor Potential (TRP) Channels and Cardiac Fibrosis
}

\author{
Zhichao Yue \\ University of Connecticut School of Medicine and Dentistry \\ Yanhui Zhang \\ University of Connecticut School of Medicine and Dentistry \\ Jia Xie \\ University of Connecticut School of Medicine and Dentistry \\ Jianmin Jiang \\ University of Connecticut School of Medicine and Dentistry \\ Lixia Yue \\ University of Connecticut School of Medicine and Dentistry
}

Follow this and additional works at: https://opencommons.uconn.edu/uchcres_articles Part of the Cardiology Commons

\section{Recommended Citation}

Yue, Zhichao; Zhang, Yanhui; Xie, Jia; Jiang, Jianmin; and Yue, Lixia, "Transient Receptor Potential (TRP) Channels and Cardiac Fibrosis" (2013). UCHC Articles - Research. 215.

https://opencommons.uconn.edu/uchcres_articles/215 


\title{
Transient Receptor Potential (TRP) Channels and Cardiac Fibrosis
}

\author{
Zhichao Yue, Yanhui Zhang, Jia Xie, Jianmin Jiang, and Lixia Yue* \\ Calhoun Cardiology Center, Department of Cell Biology, University of Connecticut Health Center, \\ Farmington, CT, USA
}

\begin{abstract}
Cardiac fibrosis is associated with most cardiac diseases. Fibrosis is an accumulation of excessive extracellular matrix proteins (ECM) synthesized by cardiac fibroblasts and myofibroblasts. Fibroblasts are the most prevalent cell type in the heart, comprising $75 \%$ of cardiac cells. Myofibroblasts are hardly present in healthy normal heart tissue, but appear abundantly in diseased hearts. Cardiac fibroblasts are activated by a variety of pathological stimuli, such as myocardial injury, oxidative stress, mechanical stretch, and elevated autocrine-paracrine mediators, thereby undergoing proliferation, differentiation to myofibroblasts, and production of various cytokines and ECM proteins. A number of signaling pathways and bioactive molecules are involved and work in concert to activate fibroblasts and myofibroblasts in the fibrogenesis cascade. Fibroblasts and myofibroblasts are not only principal ECM producers, but also play a central role in fibrogenesis and myocardial remodeling in fibrotic heart disease. Thus, understanding the biological processes of cardiac fibroblasts will provide novel insights into the underlying mechanisms of fibrosis and provide potential targets for developing anti-fibrotic drugs. Recent studies demonstrate that $\mathrm{Ca}^{2+}$ signal is essential for fibroblast proliferation, differentiation, and ECM-protein production. This review focuses on the recent advances in understanding molecular mechanisms of $\mathrm{Ca}^{2+}$ signaling in cardiac fibrogenesis, and potential role of $\mathrm{Ca}^{2+}$ permeable channels, in particular, the transient potential (TRP) channels in fibrotic heart disease. TRP channels are highly expressed in cardiac fibroblasts. TRPM7 has been shown to be essential in TGF 31 mediated fibrogenesis, and TRPC 3 has been demonstrated to play an essential role in regulating fibroblast function. Thus, the $\mathrm{Ca}^{2+}$-permeable TRP channels may serve as potential novel targets for developing anti-fibrotic drugs.
\end{abstract}

\section{Keywords}

TRP channels; fibroblasts; fibrosis; remodeling; extracellular matrix

\section{INTRODUCTION}

Fibrosis is a pathological feature common to numerous forms of heart disease, including myocardial infarction [1] arrhythmia [2-4]; ischemic, dilated, and hypertrophic cardiomyopathies, [5]; heart failure [6]; inflammatory heart disease [7]; and aging associated heart disease [8]. The fibrotic heart is characterized by abnormal conduction and impaired diastolic and systolic functions. There are two types of fibrosis, responsive and reparative

\footnotetext{
(C) 2013 Bentham Science Publishers

*Address correspondence to this author at the University of Connecticut Health Center, 263 Farmington Ave., Farmington, Connecticut, CT 06030; USA; Tel: 860-679-3869; Fax: 860-679-1426; lyue@uchc.edu.
}

The author(s) confirm that this article content has no conflict of interest. 
fibrosis $[3,9,10]$. Reparative fibrosis accompanies with cardiomyocytes death and replaces degenerating myocytes, it is therefore also referred to as replacement fibrosis. Reactive fibrosis occurs as a reaction to changes in myocardial load or inflammation without loss of cardiomyocytes, and results in interstitial fibrosis [3]. The initial reactive interstitial fibrosis is an adaptive response, and can progress into the state of replacement fibrosis, characterized by cardiomyocytes hypertrophy and necrosis [11].

Fibrosis is an accumulation of excessive extracellular matrix (ECM) proteins produced by cardiac fibroblasts and its differentiated phenotype, myofibroblasts. Fibroblasts are quiescent under normal conditions. In response to pathologic stimuli, such as myocardial injury, oxidative stress, mechanical stretch, increased level of autocrine-paracrine mediators, and inflammatory stimuli, multiple signaling pathways and various bioactive molecules act in concert to activate cardiac fibroblasts, leading to fibroblast proliferation, migration, differentiation to myofibroblasts, synthesis and release of cytokines and growth factors, production of matrix metalloproteinases (MMPs), and deposition of ECM proteins, thereby resulting in fibrosis $[12,13]$. Fibroblasts and myofibroblasts are principle producers of ECM and play a pivotal role in fibrogenesis cascades in the heart $[14,15]$. Whereas fibroblasts play an important role in supporting the structure of a normal heart by regulating mechanical, electrical, and chemical signaling between cellular and non-cellular components, myofibroblasts are rarely present in the normal healthy heart tissue. However, upon injury, myofibroblasts quickly and abundantly appear at the infarct area [16]. Myofibroblasts are more motile and can produce up to twice as much collagen as fibroblasts [17]. Cardiac myofibroblasts are responsive to proinflammatory cytokines including necrosis factor a (TNFa), interleukin-1 (Il-1), Il-6, TGF $\beta$; vasoactive peptide AngII, ET-1, ANP and BNP; and hormones such as noradrenaline. Many of the functional effects of cardiac fibroblasts under pathological conditions are mediated through differentiated myofibroblasts [18]. Therefore, transformation of quiescent fibroblasts to active ECMproducing myofibroblast is a key step in cardiac fibrogenesis cascades.

The important role of fibrosis in heart disease has been well known. However, despite a relatively sophisticated understanding of the cell biological processes underlying fibrosis, there are few effective therapies for treating fibrotic diseases [19], emphasizing the need for new insights into the underlying mechanism of fibrosis and novel targets for developing anti-fibrotic drugs. Recent studies have demonstrated that transient receptor potential (TRP) channels-mediated $\mathrm{Ca}^{2+}$ signaling plays an important role in the differentiation of fibroblast to myofibroblasts and in the fibrogenesis cascade. This review will focus on the recent developments in understanding the role of $\mathrm{Ca}^{2+}$ signals in fibrogenesis, and the potential of TRP channels as therapeutic targets for anti-fibrotic drug development.

\section{FIBROSIS IN HEART DISEASE}

Fibrosis represents excessive deposition of extracellular matrix (ECM) proteins. Cardiac fibrosis is a fundamental component of the adverse structural remodeling of the heart. It is a detrimental factor leading to abnormalities in cardiac conduction, stiffening of the ventricular walls, reduced contractility and impaired overall heart performance, thereby contributing to a variety of heart diseases including: hypertrophy, heart failure, and arrhythmia [20].

\section{Fibrosis in Ischemia Cardiomyopathy}

Fibrosis plays an important role in adverse structural remodeling of the myocardium in failing or hypertrophic hearts from ischemic cardiomyopathy (ICM) [21]. In end-stage failing human hearts caused by chronic artery diseases, collagen accumulation in the form of segmental, replacement, and interstitial fibrosis comprised an average $28 \%$ and $13 \%$ of the 
left and right ventricular myocardium, respectively [21]. The necrotic cardiomyocytes in the infarct area are replaced by fibrosis and infarct scar, and the remaining viable myocardium is corrupted by interstitial fibrosis. The infarction scar and interstitial fibrosis constitute a major cause of ventricular remodeling, leading to impaired conduction and reduced systolic and diastolic performance. In the infarct heart, angiotensin II (AngII) and angiotensin type 1 (AT1) receptors are progressively increased post-myocardial infarction [22]. AT1 receptors are localized to both macrophages and myofibroblasts [22]. Increased transforming growth factor (TGF $\beta 1$ ) expression and collagen type I were found at the infarct site and attributed to the increased number of myofibroblasts found at the infarct and remote sites. In an autocrine and paracrine manner, AngII produced by myofibroblasts up-regulates TGF $\beta 1$, which in turn increases collagen production (Fig. 1).

\section{Fibrosis in Dilated Cardiomyopathy}

Dilated cardiomyopathy is characterized by ventricular dilation of the heart. Myocytes damage in dilated cardiomyopathy can be caused by unknown reasons or known reasons such as infections and drugs [5]. Extracellular matrix proteins replace the damaged myocytes and therefore result in increased heart size. Increased interstitial levels of collagen in the left ventricle were found in dilated cardiomyopathy in the absence of other heart disease such as ischemia [23]. In patients with dilated cardiomyopathy, collagen type I and III as well as the ratio of type I/type III were all elevated [24]. Moreover, plasma levels of TGF $\beta 1$ were twice as high in patients with idiopathic dilated cardiomyopathy when compared to controls [25]. An increase in TGF $\beta$ level in macrophages and an increased number of macrophages were demonstrated in the heart of individuals with dilated cardiomyopathy [26]. In animal models, altered Smad2 and Smad4 expression in rats are associated with increased fibrosis, elevated collagen turnover and the development of dilated cardiomyopathy [27]. The importance of fibrosis in dilated cardiomyopathy suggests that antifibrotic approaches may provide a means for reversing dilation of the heart and systolic dysfunction.

\section{Fibrosis in Arrhythmia}

Fibrosis is a hallmark feature of arrhythmogenic structural remodeling in atrial fibrillation (AF) [28], the most common sustained arrhythmia in clinical practice [29]. Increased amounts of fibrous tissue occurs in AF patients who have other identifiable cardiac diseases $[30,31]$, as well as in AF patients with lone AF [30, 32]. Mice over-expressing TGF- $\beta 1$ exhibit significant atrial interstitial fibrosis with normal ventricular size and histology [33, 34], suggesting that fibrosis alone can cause AF. Atrial conduction abnormalities and enhanced susceptibility to AF occur in the absence of abnormalities in atrial action potential properties or connexin protein distribution [34], suggesting that atrial fibrosis itself creates a substrate for AF. In a congestive heart failure (CHF) dog model, it was also demonstrated that fibrosis and AF substrates persist in atria of dogs that have recovered from CHF [35, 36]. Furthermore, it has been shown that the amount of fibrosis is positively correlated with the persistence of AF [31], suggesting that atrial fibrosis results in structural remodeling to promote AF. Thus, both animal model data and AF patient data support the notion that atrial fibrosis itself can promote AF.

\section{Fibrosis in Hypertensive Heart Failure}

Fibrosis is a detrimental factor in heart failure. In hypertensive heart disease (HHD) [37], a large amount of fibrous tissues have been found and the amount of fibrosis is well correlated with the weight of the diseased hearts [38]. Fibrous tissue in the heart is composed primarily of type I fibrillar collagen with a small amount of type III collagen [6]. In hypertensive hearts, the tensile strength of the fibrious tissue is comparable to steel, making the ventricular wall very stiff and difficult for passive diastolic refilling [39-43]. In animal 
models, it was found that the regression of fibrosis resulting from treatment with AngII converting enzyme (ACE) inhibitor lisinopril was correlated with normalized left ventricular stiffness [44]. Patients receiving lisinopril also demonstrated reduced levels of circulating propeptide of procollagen type I and type III, the markers of type I and type III collagen synthesis, and normalized diastolic filling as evaluated by echocardiogram [40]. This reversal of fibrosis by pharmacological intervention indicates that anti-fibrotic treatment may alleviate heart failure by reducing the amount of cardiac fibrosis.

\section{Fibrosis in Inflammatory Heart Diseases}

Fibrosis also plays a role in inflammatory dilated cardiomyopathy (iDCM). Heart injury from many causes can lead to a common final pathway of pathologic remodeling and fibrosis, promoting heart failure development. Inflammatory dilated cardiomyopathy (iDCM) is a subtype of dilated cardiomyopathy characterized by cardiac inflammation, progressively impaired contractility, tissue fibrosis, and ventricular dilation [7]. Cardiac inflammation, or myocarditis, usually results from infections with various viruses (Chagas disease), and it is often associated with autoimmune response against heart tissue antigen [7]. In iDCM, fibrosis results as a consequence of infiltration of granulocytes, monocytes, macrophages, dendritic cells, mast cells, and $\mathrm{T}$ and $\mathrm{B}$ lymphocytes.

\section{Fibrosis in Aging Heart}

Myocardial aging is characterized by left ventricular (LV) fibrosis leading to diastolic and systolic dysfunction. Extensive evidence derived from both clinical and experimental studies suggests that the aging heart undergoes fibrotic remodeling [8]. Several distinct molecular pathways, such as reactive oxygen species (ROS), TGF $\beta$ activation, endothelin-1 and AngII signaling, may contribute to age-dependent fibrogenesis. In addition, aging is associated with an impaired reparative response to cardiac injury and defective activation of reparative fibroblasts in response to growth factors. Because these reparative defects result in defective scar formation, senescent hearts are prone to adverse dilative remodeling following myocardial infarction [8]. Moreover, a progressive decline in circulating C-type natriuretic peptide (CNP) is strongly associated with a reciprocal increase in fibrosis, which precedes impairment of diastolic and systolic function [45]. Thus, a better understanding of the pathogenesis of interstitial fibrosis is critical to developing new strategies for preventing of adverse remodeling and heart failure in elderly patients.

In summary, fibrosis is a hallmark feature of most heart disease. However, there are few effective therapies for fibrotic heart diseases, emphasizing the need for a better understanding of the underlying mechanism of fibrosis.

\section{SIGNALING PATHWAYS INVOLVED IN CARDIAC FIBROSIS}

Several signaling pathways and many bioactive molecules that cause profibrotic responses often work in concert in the fibrogenesis cascades [46]. There are at least three well-known common interrelated pathways involved in fibrosis including the rennin-angiotensin system, TGF 31 , and oxidative stress pathway. The rennin-angiotensin system plays a central role in cardiac structural remodeling and in the development of myocardial fibrosis in several disease states including CHF [47], myocardial infarction [48], and cardiomyopathy [49]. ROS production is elevated by AngII and hypertension [50, 51]. In response to hypoxia, fibroblasts differentiate to myofibroblasts [52], thereby initiating the fibrotic process. Both AngII and oxidative stress induce collagen in vivo and in vitro. Oxidative stress also contributes to cardiac fibrosis in the heart of diabetic rats [53]. TGF $\beta 1$ is a central bioactive molecule in the fibrogenesis cascades. TGF $\beta 1$ is a downstream mediator of AngII, and TGF $\beta 1$ also regulates AngII expression level. Other bioactive mediators such as PDGF, 
endothelin (ET), and connective tissue growth factor (CTGF), have also been demonstrated to play important roles in cardiac fibrosis (Fig. 1).

\section{Angll}

The rennin-angiotensin-aldosterone system plays an important role in cardiac fibrosis in hypertensive heart disease, CHF, myocardial infarction and cardiomyopathy [54]. AngII level is elevated in overloaded hearts with fibrosis [55]. Increased local AngII production is associated with myocyte apoptosis and reactive interstitial fibrosis [56]. AngII can induce proliferation and differentiation of cardiac fibroblasts, induce ECM protein synthesis, and decrease MMP activity and increase TIMP activity [18]. It appears that the profibrotic effect of AngII is dependent on TGF $\beta 1$. In the absence of TGF $\beta 1$, AngII is unable to induce cardiac hypertrophy [57]. AngII significantly up-regulates TGF $\beta 1$ expression through the AT1 receptor in cardiac myocytes and fibroblasts [58]. TGF $\beta 1$ in turn can directly stimulate AT1 receptor expression through T $\beta R 1$ and Smad2/3/4 [59]. AngII can also exert its effects independent of TGF $\beta$. In cardiac fibroblasts, AngII also induces collagen synthesis through ERK pathways [60]. Furthermore, p38 mitogen-activated kinase, JNK, and phosphatidylinositol 3-kinase (PI3K) signaling pathways also appear to be involved in TGF $\beta 1$-stimulated AT1 receptor expression [59]. AngII is a major component in the fibrogenesis network (Fig. 1).

\section{TGF $\beta$}

TGF $\beta$ plays a central role in cardiac fibrogenesis cascades. Extensive studies have demonstrated that TGF $\beta$ is a potent activator of cardiac fibrosis $[33,57]$. TGF $\beta$ is the prototype of a large family of cytokines [61]. There are three TGF $\beta$ isoforms in mammals, namely TGF $\beta 1$, TGF $\beta 2$ and TGF $\beta 3$ expressed in myofibroblasts, vascular smooth muscle cells, endothelial cells, and macrophage [62]. The human TGF $\beta 1$ gene produces a 390 amino acid propetide which is cleaved intracellularly to two identical 112 amino acid peptide subunits joined together by a disulphide bond [63].

TGF $\beta 1$ is secreted initially as a biological inactive molecule bound to latent associated peptides [64]. Latent TGF $\beta 1$ can be activated by cell-cell interaction, acidification, and enzyme cleavage [63]. TGF $\beta 1$ exerts its biological function through a heteomeric receptor complex comprising of two serine-threonine kinase receptors T $\beta R 1$ and T $\beta R 2$. Both TGF $\beta$ ligand and receptors are present in cardiac myocytes and fibroblasts [65]. The T $\beta R 1$ is an activin linked kinase 5 (ALK5) which can phosphorylate Smad2 and Smad3, leading to translocation of Smad2/3 to the nucleus, and activate transcription of target genes. Conversely, TGF $\beta$ signaling is inhibited by Smad7. Phosphorylated Smad2 levels are increasingly high in hypertension-induced heart failure [66]. Since Smad2/3 are weak transcriptional factors, they work with co-activators such as AP-1, SP-1, TFE3 and p300 to activate promoters of fibrosis associated genes such as collagen type 1 [67]. TGF $\beta$ also activates a variety of noncanonical signaling pathways including ras/MEK/ERK, p38, and TAK1 [68-70] (Fig. 1).

TGF $\beta$ activates TAK1/p38 signaling pathways through transcriptional factor ATF2 to regulate cardiac fibrosis [71]. Transgenic mice over-expressing TAK1 develop hypertrophy, interstitial fibrosis, and severe myocardial dysfunction [72]. A recent study demonstrated that TGF $\beta$ activates the nuclear translocation of MRTA-F through Rho/ROCK signaling in cardiac fibroblasts, inducing a subset of genes such as $\beta$-smooth muscle actin ( $\beta S M A$ ) expressed in myofibroblasts [73]. MRTA-A is a myocardin-related transcription factor A (MRTF-A), a co-factor of serum response factor (SRF). Genetic deletion of MRTF-A in mice abrogated fibrosis induced by myocardial infarction [73]. It was also demonstrated that 
Rho kinase activity is increased in cardiac fibrosis, and that Rho kinase inhibitor prevented cardiac fibrosis in mice treated with aldosterone [74].

By activating the TGF $\beta 1$-Smad pathway and noncanonical pathways, TGF $\beta 1$ induces the synthesis and release of extracellular matrix proteins (ECM). Meanwhile, TGF $\beta 1$ interacts with matrix metalloproteinases (MMPs). It has been found that both MMP-2 levels and the levels of membrane type-MMP (MT-MMP) are higher in terminally failing heart, in concordance with when TGF $\beta 1$ expression is also increased [75]. In the myocardium of infarcted rats, both TGF $\beta 1$ and MMP-2 were elevated [76]. TGF $\beta 1$ induced expression of MMP-2 facilitates migration and motility of cardiac fibroblasts, which in turn leads to the local production of ECM and increased fibrosis within the myocardium of the heart associated with cardiac remodeling.

\section{Endothelin (ET)}

ET is a potent vasoconstrictor and plays an important role in chronic heart failure. ET is secreted from endothelial cells. Among the three isoforms of ET, namely ET-1, ET-2, and ET-3 [77, 78], ET-1 is the major isoform in humans, which can be produced by endothelial cells but is also expressed by epithelial cells, bone marrow mast cells, macrophages, polymorphonuclear leukocytes, cardiomyocytes, and fibroblasts [79]. ET-1 induces ECM production and myofibroblast differentiation. TGF $\beta$ induces ET-1 via JNK, and ET-1 is a downstream mediator of the fibrogenic response of TGF $\beta$ in normal fibroblasts [80]. AngII can also induce ET-1 via ERK and reactive oxygen species [81] (Fig. 1).

\section{Connective Tissue Growth Factor (CTGF)}

CTGF is a matricellular protein [82] and an excellent surrogate marker for activated fibroblasts in wound healing and in fibrosis. CTGF is also called CCN2. The name CCN is an abbreviation derived from the main members: Cysterine-rich 61 (Cyr61/ CCN1), CTGF (CCN2) and Nephroblastoma (Nov/CCN3) [83]. CTGF is predominantly expressed in fibroblasts in the healthy heart, but is also secreted by myocytes in the process of cardiac remodeling $[84,85]$. CCN2 is significantly induced in cardiac myocytes by TGF $\beta$, AngII and ET-1 [86]. TGF $\beta$ induces CTGF expression through signaling cascades involving Smads, Ets-1, and ras/MEK/ERK [87]. CCN2 promotes cell adhesion and enhances adhesive signaling thereby creating an environment favorable for fibrogenic stimuli to act $[88,89]$. Although direct evidence functionally linking CCN2 to cardiac disease is scant, $\mathrm{CCN} 2$ has been shown both in vitro and in vivo to cause hypertrophy of rat cardiomyocytes $[88,90]$.

\section{PDGF (Platelet-Derived Growth Factor)}

PDGF comprises a family of homo- or hetero-dimeric growth factors including PDGF-AA, PDGF-AB, PDGF-BB, PDGF-CC, and PDGF-DD. There are different PDGF receptors, $\beta$ and $\beta$ [91]. Elevated PDGF-DD expression is observed postwounding [92]. PDGF causes fibroblasts, neutrophils, macrophages, and smooth muscle cells to proliferate and migrate into the wound site [93, 94]. PDGF also stimulate granulation tissue formation [93, 94], and stimulates fibroblasts to contract on collagen matrix and differentiate into myofibroblasts in vitro $[95,96]$. In animal studies, transgenic mice expressing an active core domain of PDGF-D develop interstitial fibrosis followed by dilated cardiomyopathy and subsequent cardiac failure [97]. PDGF-D stimulates proliferation of interstitial fibroblasts and arterial smooth muscle cells via PDGFR- $\beta$ signaling. When PDGF-C is over-expressed in the heart, transgenic mice exhibited cardiac fibrosis which resulted in hypertrophy in male mice and dilated cardiomyopathy, heart failure and sudden death in female mice [98]. Overexpression of PDGF-C also led to vascular defects which were likely caused by an upregulation of vascular endothelial growth factor in cardiac fibroblasts of the transgenic mice 
[98]. In the pressure-overloaded mouse hearts, infiltrated mast cells release PDGF-A, promoting the fibrogenic process, thereby leading to atrial fibrosis and enhanced AF susceptibility [99]. It appears that PDGF and PDGF receptor (PDGFR) are differentially expressed in atria and ventricles. Burstein and colleagues found that PDGF and PDGF receptor gene expression levels were much higher in normal atrium compared with ventricle. In a congestive heart failure dog model, PDGF and PDGFR were also differentially enhanced in atria versus ventricles [100]. The differential expression of PDGF and PDGFR in atria and ventricles may explain the enhanced AF susceptibility in pressure-overloaded hearts [99].

In summary, multiple signaling pathways, mediators, and cells types are involved in the cardiac fibrogenesis cascade. However, the final common effector for different pathways is the cardiac fibroblast (Fig. 1). Thus, understanding fibroblast biology is crucial for developing anti-fibrotic drugs.

\section{CARDIAC FIBROBLAST IS A KEY REGULATOR OF CARDIAC FIBROSIS}

\section{Cardiac Fibroblasts and Myofibroblasts}

Although the signaling molecules involved in fibrosis are generated in various cell types, cardiac fibroblast and myofibroblast are the major cell types which synthesize and deposit extracellular matrix proteins (ECM). Cardiac fibroblast represents the most prevalent cell type in the heart. Almost $75 \%$ of cardiac cells are fibroblasts. However, because of their small cell size, fibroblasts contribute to only $10-15 \%$ of cardiac cell volume. While there is considerable knowledge concerning the properties and functions of cardiomyocytes, much less is known about cardiac fibroblasts. Cardiac fibroblasts are mostly known for their role in the synthesis and remodeling of the ECM in the heart, but they are more than just matrix producing cells. Fibroblasts are intricately involved in myocardial development [101]. Moreover, fibroblasts can sense changes in their microenvironment and react to these changes in order to preserve organ function. Furthermore, cardiac fibroblasts can synthesize a variety of bio-active molecules and secrete them into the surrounding interstitium, thereby exerting autocrine/paracrine effects by not only acting on various cell types but also on the fibroblasts themselves. The bioactive molecules synthesized by fibroblasts include TNFa, IL-1 $\beta$, IL-6, TGF $\beta$, AngII, ET-1, ANP and BNP [18]. These molecules are synthesized and secreted under different stimuli, and also act on different cell types. Overall, cardiac fibroblasts contribute to the structural, mechanical, biochemical, and electrical properties of the heart, and play a crucial role in cardiac pathophysiology [102].

\section{Differentiation of Fibroblasts to Myofibroblasts}

Fibroblasts are quiescent under normal conditions. When exposed to pathological stimuli such as myocardial injury, oxidative stress, mechanical stretch, and inflammatory stimuli, fibroblasts undergo phenotypic changes and differentiate to myofibroblasts. Myofibroblasts are rarely present in normal healthy cardiac tissue [16], with the exception of the heart valve leaflet. However, upon injury, myofibroblasts abundantly appear at the infarct area. Myofibroblasts express a-smooth muscle action, and exhibit increased migratory, proliferative, and secretary properties. Myofibroblasts can produce up to twice as much collagen as their precursor fibroblasts [17]. Myofibroblasts can be differentiated from resident fibroblasts, or fibroblasts from circulation. Irrespective of their origin, myofibroblasts produce growth factor, cytokines, ECM proteins, and proteases. Cardiac myofibroblasts are particularly responsive to proinflammatory cytokines including necrosis factor $\beta$ (TNFa), interleukin-1 (Il-1), Il-6, TGF $\beta$; vasoactive peptide AngII, ET-1, ANP and BNP; and hormones such as noradrenaline. Thus, the transformation of quiescent fibroblasts to active matrix-producing myofibroblasts is a key step in disease progression. 


\section{CALCIUM SIGNALING IN FIBROBLASTS IS CRUCIAL TO FIBROGENESIS}

\section{Electrophysiological Properties of Cardiac Fibroblasts}

Resting membrane potential-The electrophysiological properties of cardiac fibroblast will influence their abilities to exhibit excitation-secretion coupling, fibroblast-myocyte coupling as well as fibroblast-fibroblast interactions. While the resting membrane potential of cardiac myocytes is usually about $-80 \mathrm{mV}$, fibroblasts have a much more positive resting membrane potential. Using conventional intracellular sharp microelectrode recording, it was reported that the resting membrane potential of cardiac fibroblasts in situ is between -31 and $-16 \mathrm{mV}[103,104]$. Patch-clamp recordings in isolated rat atrial fibroblasts demonstrate that the resting membrane potential is about $-37 \mathrm{mV}$ [105]. It is not fully understood which channels determine resting membrane potential in cardiac fibroblasts. The inward rectifier potassium current $\mathrm{I}_{\mathrm{K} 1}$ which is likely encoded by Kir 2.1 may contribute to resting membrane potential [106]. However, $\mathrm{I}_{\mathrm{K} 1}$ currents have only been recorded in myofibroblasts but not in fibroblasts [106]. Further investigation is required to understand the determinants of resting membrane potential in cardiac fibroblasts.

Ion Channels in Cardiac Fibroblasts-The voltage-gated $\mathrm{Na}^{+}$and $\mathrm{K}^{+}$channels have been demonstrated in cardiac fibroblasts. The transient-outward $\mathrm{K}^{+}$-current $\left(\mathrm{I}_{\mathrm{to}}\right)$, and two types of kinetically-distinct delayed-rectifier $\mathrm{K}^{+}$-currents have been demonstrated in rat ventricular fibroblasts $[107,108]$. Although the detailed molecular basis of these voltagegated $\mathrm{K}^{+}$channel is unclear, it has been shown that Kv1.2, Kv1.4, Kv1.5, and Kv2.1 asubunits, but not Kv4.2 or Kv1.6 a-subunits are expressed at protein level detected by Immunoblot analysis [108]. $\mathrm{Li}$ and colleagues demonstrated that there are two types of voltage-gated $\mathrm{Na}$ currents in human ventricular fibroblasts, tetrodotoxin-sensitive $\left(\mathrm{I}_{\mathrm{Na} . T T X}\right)$ and TTX-resistance ( $\mathrm{I}_{\mathrm{Na}}$.TTXR $)$ Na currents [109]. The $\mathrm{Na}_{\mathrm{v}} 1.3$, Nav1.6 and Nav1.7 were detected in those human ventricular fibroblasts. Moreover, delayed rectifier $\mathrm{I}_{\mathrm{K}}, \mathrm{I}_{\mathrm{to}}, \mathrm{Ca}^{2+}$ activated $\mathrm{K}^{+}$current $\left(\mathrm{BK}_{\mathrm{Ca}}\right)$, inward-rectifier (Kir-type), and swelling-induced $\mathrm{Cl}^{-}$current $\left(\mathrm{I}_{\mathrm{Cl} . v o l}\right)$ channels are also present in these commercially available human cardiac fibroblasts (HCF, CELL Applications Inc.) [109]. Recently, Chatelier and colleagues demonstrated that the TTX-resistant $\mathrm{I}_{\mathrm{Na}}\left(\mathrm{IC}_{50}\right.$ is $\left.\sim 1 \mu \mathrm{M}\right)$ in isolated and cultured human atrial myofibroblasts, but not in the freshly isolated fibroblasts [110]. This $\mathrm{I}_{\mathrm{Na}}$ exhibits similar properties to that of $\mathrm{I}_{\mathrm{Na}}$ in the cardiac myocytes. The $\mathrm{Na}_{\mathrm{v}} 1.5 \mathrm{a}$-subunit and the $\beta 1$-subunit are markedly larger in myofibroblasts than in fibroblasts, suggesting that $\mathrm{I}_{\mathrm{Na}}$ in myofibroblasts is encoded by $\mathrm{Na}_{\mathrm{V}} 1.5$ [110]. It is of great interest to understand the potential role of $\mathrm{I}_{\mathrm{Na}}$ in fibroblast biology and in fibrogenesis cascade. For the non-voltage gated $\mathrm{K}^{+}$channels, the $\mathrm{K}_{\mathrm{ATP}}$ channel has been reported in mouse cardiac fibroblasts, and it is likely to be encoded by SUR2/Kir6.1 [111]. Whereas the function of $\mathrm{I}_{\mathrm{Na}}$ is unclear, it has been shown that changes of resting membrane potential by manipulating $\mathrm{I}_{\mathrm{K} 1}$ current amplitude in rat ventricular fibroblasts influences myofibroblast proliferation [106]. Moreover, activation of $\mathrm{I}_{\mathrm{KATP}}$ in mouse cardiac fibroblasts results in an increase in cell proliferation and a decrease in IL-6 secretion [112]. The I KATP is also activated by sphingosine-1-phosphate (S1P) through S1P receptor 3 (S1P3R), resulting in cell proliferation and decreases in IL-6 and collagen secretions [111]. In human atrial fibroblasts, a voltage-gated proton $\left(\mathrm{H}^{+}\right)$-permeable current has also been demonstrated [113], although its function is unclear. Recently, He and colleagues demonstrate that $\mathrm{BK}_{\mathrm{Ca}}$ and $\mathrm{I}_{\mathrm{Cl} \text {.vol }}$ channels, but not $\mathrm{Na}^{+}$channels, are involved in the regulation of proliferation of cultured human cardiac fibroblasts [114]. It will be important to determine whether and how the various ion channels in fibroblasts contribute to basic fibroblast function, as well as to fibroblast-cardiomyocyte interactions. 


\section{$\mathrm{Ca}^{2+}$-Signaling in Cardiac Fibroblast Functions}

$\mathrm{Ca}^{2+}$ signals are essential for a variety of cellular functions including differentiation, gene expression, cell proliferation, growth and death $[115,116]$. However, unlike cardiac myocyes, $\mathrm{Ca}^{2+}$ signaling mechanisms in cardiac fibroblasts are not fully understood. The importance of $\mathrm{Ca}^{2+}$ in fibroblasts biology was first reported in 1996 [117]. Kiseleva and colleagues demonstrated that $\mathrm{Ca}^{2+}$ entry through a stretch-activated channel in the plasma membrane and $\mathrm{Ca}^{2+}$ release from the endoplasmic reticulum play key roles in the generation of a mechanical-induced-potential (MIP) in rat cardiac fibroblasts [117]. Chelating internal and external $\mathrm{Ca}^{2+}$ inhibits MIP. In addition, the MIP was reduced in the chronic infarct rat hearts [118]. The stretch-induced current in fibroblasts can be blocked by a non-selective cation channel blocker gadolinium $\left(\mathrm{Gd}^{3+}\right)$ [105], suggesting that non-selective channels may contribute to the stretch-induced currents. Furthermore, several lines of evidence suggest that $\mathrm{Ca}^{2+}$-entry is essential for fibroblasts' biological functions. When external $\mathrm{Ca}^{2+}$ is chelated by EGTA, the substance P-induced proliferation of cultured rat cardiac fibroblasts is inhibited $[119,120]$. Eliminating external $\mathrm{Ca}^{2+}$ to prevent $\mathrm{Ca}^{2+}$ influx also attenuates $\mathrm{H}_{2} \mathrm{O}_{2}$-induced IL-6 mRNA expression in fibroblasts [121]. In an in vivo study, mibefradil, a non-selective $\mathrm{L}$ - and $\mathrm{T}$-type $\mathrm{Ca}^{2+}$-channel blocker, reduced collagen production and fibroblast differentiation in rats treated with AngII or aldosterone [122]. Taken together, these studies indicate that $\mathrm{Ca}^{2+}$ release and $\mathrm{Ca}^{2+}$ entry through $\mathrm{Ca}^{2+}$ permeable channels are essential for biological functions of cardiac fibroblasts.

\section{$\mathrm{Ca}^{2+}$ Release Mechanism in Cardiac Fibroblasts}

As a previous study demonstrated, ryanodine receptor (RyRs) blockers and activators can change MIP, presumably through RyRs [117]. However, in human cardiac fibroblasts (HCF, CELL Applications Inc.), Chen and colleagues reported that the $\mathrm{IP}_{3}$ receptors (IP3Rs) but not the RyRs were detectable by RT-PCR [123]. Accordingly, the $\mathrm{Ca}^{2+}$ oscillations were not influenced by ryanodine or caffeine, but were blocked by PLC blocker U73122 [123]. Moreover, $\mathrm{Ca}^{2+}$ channel blocker nifedipine and activator BayK8644 did not affect $\mathrm{Ca}^{2+}$ oscillation, suggesting that the L-type $\mathrm{Ca}^{2+}$ channels are not involved in the $\mathrm{Ca}^{2+}$ signaling in fibroblasts. Indeed, $\mathrm{L}$-type $\mathrm{Ca}^{2+}$ current has not been reported in cardiac fibroblasts so far. In contrast, the non-specific blocker $\mathrm{La}^{3+}$ eliminated the $\mathrm{Ca}^{2+}$ oscillations. Other $\mathrm{Ca}^{2+}$ signaling components include three types of SERCA, and the plasma membrane $\mathrm{Ca}^{2+}$ pump (PMAC) type 1, 3 and 4 detectable by RT-PCR in the human fibroblasts [123]. Chen and colleagues also demonstrated the expression of all the TRPC channel genes and the Orai1-3 genes detected by RT-PCR [123].

\section{TRP Channels in Cardiac Fibroblasts}

Overview of TRP Channels-The first trp channel gene was cloned in Drosophila [124, 125]. A large superfamily of TRP channels containing 28 TRP channel genes has been identified in mammals. This superfamily of TRP channel share a common structural containing six putative transmembrane domains. Based on sequence homology, the mammalian TRP channel superfamily can be classified into six subfamilies: TRPC, TRPV, TRPM, TRPA, TRPP and TRPML [126-128]. The canonical TRP channel subfamily (TRPC) contains seven members (TRPC1-7). Many of the TRPC channels are activated by $\mathrm{G}_{\mathrm{q}}$-linked receptor activation, among which TRPC 3 and TRPC 6 can also be activated by diaglycerol (DAG) [129]. TRPC channels often form heterotetrameric channels. For example, TRPC1/TRPC4/TRPC5, or TRPC3/TRPC6/ TRPC7 can form functional channels [130]. The TRPV (vanilloid) subfamily comprises six members (TRPV1-6), and several TRPV channel are activated by noxious temperature [126-128]. The melastatin subfamily (TRPM) includes eight TRP channels (TRPM1-8). TRPM2, TRPM6 and TRPM7 not only 
have channel function, but also contain an enzyme domain at the C-termini. The TRPP (polycystin) and TRPML (mucolipin) families are intracellular ion-channels [131].

Many of the TRP channels are $\mathrm{Ca}^{2+}$-permeable non-selective cation channels, except that TRPM4 and TRPM5 are monovalent cation selective channels. Most $\mathrm{Ca}^{2+}$-permeable TRP channels are poorly-selective for $\mathrm{Ca}^{2+}$, with $\mathrm{Ca}^{2+} / \mathrm{Na}^{+}$permeability ratios $\left(P_{\mathrm{Ca}} / P_{\mathrm{Na}}\right)$ between 0.3 and 10, but TRPV5 and TRPV6 are highly $\mathrm{Ca}^{2+}$-selective, with $P_{\mathrm{Ca}} / P_{\mathrm{Na}}>100$ $[132,133]$. Unlike voltage-gated ion channels, TRP channels lack a full complement of charged aminoacids in the S4 domain and are very weakly voltage-responsive [126, 127]. The activation mechanisms of TRP channel are highly diversified. Some TRP channels appear to be constitutively active, whereas others are activated by $\mathrm{G}_{\mathrm{q}}$-linked receptor activation, oxidative stress, changes of temperature, or an elevation of intracellular $\mathrm{Ca}^{2+}$ [126-128]. All the TRP channels appear to be regulated by PIP 2 [134-137]. The unique features of TRP channels, such as $\mathrm{Ca}^{2+}$-permeation, non-voltage gating property, and diversified activation mechanisms such as by receptor activation, stretch and oxidative stress, make TRPs the best candidate for mediating $\mathrm{Ca}^{2+}$ entry into cardiac fibroblasts.

TRP Channels in Cardiac Fibroblasts-Expression of TRP channels can be readily detected by RT-PCR in the heart [138]. While many studies use cardiac tissues containing cardiomyocytes, fibroblasts and other cell types [139], there are a number of reports that used isolated or culture fibroblasts. In isolated rat ventricular fibroblasts, TRPC2, TRPC3, and TRPC5 mRNA were detected by RT-PCR [140]. Nishida and colleagues reported the presence of TRPC1, TRPC3, TRPC6, and TRPC7 in rat cardiac fibro-blasts [141]. In cultured human cardiac fibroblasts (HCF), TRPC1, TRPC4, and TRPC6 were found to be abundantly expressed at mRNA levels [123]. In freshly isolated human atrial fibroblasts, several TRP channels including TRPC1, TRPC6, TRPV2, TRPV4, and TRPM7 are readily detected by RT-PCR [142]. In mouse cardiac fibroblasts, TRPC1, TRPC3, TRPC4, TRPC6, TRPV2, TRPV4, TRPM4, TRPM6, and TRPM7 were all detected by RT-PCR [142]. Although the expression of TRP channels can be readily detected by RT-PCR, many of those TRP channels have not been able to be detected by electrophysiological recordings.

The first TRP channel current recorded in cardiac fibroblasts was TRPM7 [143]. TRPM7 currents recorded from rat ventricular fibroblasts were blocked by activation of $\mathrm{G}_{\mathrm{q}}$-linked receptor EDG-7, a similar property to the over-expressed TRPM7 currents [143]. TRPM7 is abundantly expressed in cardiac fibroblasts and is a major $\mathrm{Ca}^{2+}$-permeable channel in human and mouse cardiac fibroblasts [142]. In freshly-isolated rat ventricular fibroblasts, Rose and colleagues have demonstrated a non-selective cation current (NSCC) which can be elicited by CNP (C-type natriuretic peptide) and cANP [140]. The cANF induced currents were eliminated in fibroblasts pre-treated with $0.5 \mu \mathrm{g} / \mathrm{ml}$ PTX for 3 hour, indicating the involvement of $\mathrm{G}_{\mathrm{i} / \mathrm{o}}$ protein in activation of NSCC. Moreover, the cANF induced currents were blocked by $10 \mu \mathrm{M} \mathrm{Gd}^{3+}, 50 \mu \mathrm{M}$ SKF 96365 and $100 \mu \mathrm{M}$ 2-APB. U73122 but not U73343 also inhibited the cANF induced currents, suggesting the involvement of the PLC $\beta$ pathway in inducing channel activation. Moreover, activation of the NSCC can also be induced by OAG (1-oleoyl-2-acety-sn-glycerol) [140], suggesting that TRPC3, TRPC6, or TRPC3/TRPC6 heteromers may underlie the molecular basis of the CNP activated NSCC in rat ventricular fibroblasts [140]. In a recent elegant study, Harada and colleagues demonstrated TRPC3 currents recorded in rat cardiac fibroblasts [144], and found that TRPC 3 regulates fibroblast function in atrial fibrillation. Other TRP channel currents which have been recorded by electrophysiological method or $\mathrm{Ca}^{2+}$ influx approach include TRPM2 and TRPV4 [145, 146]. Rat cardiac fibroblasts exposed to hypoxia conditions for 24 hours exhibit a linear TRPM2-like current. The TRPM2-like currents can be inhibited by Clotrimazole with an $\mathrm{IC}_{50}$ of $0.7 \mu \mathrm{M}$. TRPM2 siRNA reduced the current amplitude and TRPM2 mRNA level in fibroblasts treated with hypoxia, suggesting hypoxia up-regulates 
TRPM2 in rat cardiac fibroblasts [145]. Although the potential role of TRPM2 in fibroblasts was not investigated, it is conceivable that TRPM2 may be involved in oxidative stress associated fibrosis. Using 4a-12,13-didecanoate (4a-PDD) as an activator, Hatano and colleagues recorded TRPV4 current in rat cardiac fibroblasts. The 4a-PDD induced TRPV4 current was blocked by ruthenium red, and reduced by TRPV4 siRNA [146]. It will be of interest to investigate the potential role of TRPV4 in fibroblast biology and pathogenesis of fibrosis

\section{TRP CHANNELS IN CARDIAC FIBROSIS}

\section{TRPM7-Mediated $\mathrm{Ca}^{2+}$ Signal Regulates TGF $\beta 1$ Induced Fibrogenesis}

TRPM7 is a unique ion channel that possesses protein kinase function [147-149]. It is permeable to $\mathrm{Ca}^{2+}$ and $\mathrm{Mg}^{2+}$ under physiological conditions; and to $\mathrm{Na}^{+}$under acidic extracellular conditions. TRPM7 is constitutively active under physiological conditions and conducts a small inward current $[147,148]$. Depletion of $\mathrm{PIP}_{2}$ by stimulation of $\mathrm{G}_{\mathrm{q}}$-linked receptors inactivates TRPM7 [143], whereas extracellular acidosis potentiates monovalent inward currents of TRPM7 $[150,151]$. TRPM7 plays a vital role in embryonic development [152-155], anoxia/ischemia induced neuronal death [156, 157], $\mathrm{Mg}^{2+}$ homeostasis [153, 158], apoptosis [159], cell migration [160], breast tumor cell metastasis [161], and various other cellular functions [162-165].

TRPM7 is ubiquitously expressed in various cells and tissues. In cardiac fibroblasts, TRPM7 is the major $\mathrm{Ca}^{2+}$-permeable channel. TRPM7 current density is up-regulated by $3 \sim 5$ fold in fibroblasts from AF patients compared with sinus rhythm patients [142]. Consistent with the changes of TRPM7 in fibroblasts, TRPM7 is also up-regulated in cardiac myocytes from AF patients [166]. In AF fibroblasts, $\mathrm{Ca}^{2+}$ influx is much larger than that in control fibroblasts. $\mathrm{Ca}^{2+}$ influx is largely diminished after TRPM7 is knocked down by shRNA. TRPM7 shRNA not only inhibits TRPM7 currents and $\mathrm{Ca}^{2+}$ influx, but also inhibits TGF- $\beta 1$-induced fibroblast proliferation, differentiation and collagen-production [142]. Moreover, TRPM7 is also up-regulated by TGF- $\beta 1$ in cultured fibroblasts. It appears that TRPM7-mediated $\mathrm{Ca}^{2+}$ signals play a pivotal role in fibroblast differentiation in human $\mathrm{AF}$ and mediate the fibrogenic effect of TGF- $\beta 1$. Since fibrosis is one of the major detrimental factors of AF, and TGF $\beta 1$ is a potent promoter of fibroblast differentiation and fibrogenesis, the effects of TRPM7 in TGF $\beta 1$ mediated fibrosis suggest that TRPM7 may serve as an effective therapeutic target for cardiac fibrosis.

\section{TRPC3 Regulating Cardiac Fibroblast in AF}

The important role of TRPC channels in cardiac hypertrophy has been extensively studied and has been nicely reviewed $[138,167]$. It appears that TRPC1, TRPC3, TRPC4, TRPC5, TRPC6, and TRPC7 [168] are all involved in cardiac hypertrophy [138, 167, 169]. TRPC6 is essential for the development of cardiac hypertrophy in the mouse model, and is upregulated in patients with heart failure [170]. Cardiac-specific expression of dominantnegative TRPC3 attenuates cardiac hypertrophic responses to neuroendocrine agonistinfusion or pressure-overload [171]. Both TRPC3 and TRPC6 play a role in AngII-induced NFAT nuclear-translocation in rat cardiomyocytes [172], a crucial step in cardiac hypertrophy[173].

While most studies about TRPC functions in the heart demonstrate that TRPC channels are involved in $\mathrm{Ca}^{2+}$ signaling in myocytes, Harada and colleagues recently reported that TRPC3 plays a role in regulating fibroblast function, and thereby influences AF development. In this elegant study, Harada and colleagues demonstrated that TRPC3 is highly expressed in freshly isolated fibroblasts, but almost diminished in differentiated myofibroblasts [144]. TRPC3 blocker pyrazole-3 inhibited AngII-induced $\mathrm{Ca}^{2+}$ influx, and 
fibroblast proliferation and differentiation. Inhibition of TRPC3 suppressed extracellularsignal regulated kinase (ERK)-phosphorylation, resulting in reduced fibroblast proliferation. The $\mathrm{Ca}^{2+}$ mediated fibroblast proliferation and differentiation through ERK1/2phosphorylation pathway was not observed in TRPC6-mediated $\mathrm{Ca}^{2+}$ in cultured neonatal cardiac fibroblasts [141]. Nashida and colleagues found that ERK1/2 phosphorylation was not affected by ET-1-activated TRPC 6 currents. Instead, TRPC6-mediated $\mathrm{Ca}^{2+}$ by ET1 stimulation activates NFAT, which works as a negative regulator against ET-1-induced fibroblasts differentiation [141]. Whereas the effects of TRPC6 on fibroblasts were evaluated in cultured neonatal fibroblasts [141], which may have contributed to the discrepancy between these two studies, the function of TRPC 3 was evaluated at multiple levels, including cultured adult fibroblasts from rats and dog, in vivo studies, and in samples from AF patients [144]. Harada and colleagues found that TRPC 3 is up-regulated in atria from $\mathrm{AF}$ patients, goats with electrically-maintained AF, and tachypacing-induced heartfailure dogs [144]. More importantly, it was demonstrated that the TRPC 3 blocker pyrazole-3 was able to prevent the development of the AF substrate in a dog model of electrically-maintained AF. Thus, reducing TRPC3-mediated $\mathrm{Ca}^{2+}$ is likely to reduce the susceptibility of AF, and TRPC3 may serve as a novel potential therapeutic target for fibrotic associated AF [144].

In summary, many TRP channels have been identified in cardiac fibroblasts. However, their physiological and pathological functions are yet to be determined. It is likely that more TRP channel functions in cardiac fibrogenesis will be unveiled in the future.

\section{THERAPEUTIC IMPLICATIONS}

As cardiac fibrosis is a hallmark of most cardiac pathologies, anti-fibrotic strategies are increasingly recognized as a promising approach in the prevention and treatment of fibrotic heart diseases. A number of therapeutic agents for cardiovascular diseases have been shown to exert pleiotropic effects on fibroblasts that underlie some of their potential benefits on cardiac fibrosis and myocardial remodeling. For example, ACE inhibitors and AngII receptor blockers (ARBs) inhibit AngII induced fibroblast proliferation, differentiation, ECM turnover, and synthesis of cytokines and growth factors, thereby inhibiting fibrosis [18]. The lipid lowering drugs Statin inhibits fibroblast proliferation and exerts antifibrotic effects [174] possibly via anti-inflammatory/antioxidant actions. Pirfenidone prevents the development of a vulnerable substrate for atrial fibrillation resulting from CHF by suppressing atrial fibrosis [175].

The important role of TRP channels in regulating $\mathrm{Ca}^{2+}$ signals in cardiac fibroblasts provides a new direction of therapeutic target for fibrotic heart disease. TRPM7-mediated $\mathrm{Ca}^{2+}$ regulates fibroblast proliferation, differentiation, and ECM-protein production profiles [142]. TRPC3 inhibitor pyrazole-3 administrated in vivo suppressed AF by reducing fibrosis [144]. Thus, TRPM7 and TRPC3 are potential therapeutic targets for fibrotic heart disease. Since a variety of TRP channels are also expressed in cardiac myocytes and contribute to cardiac hypertrophy and heart failure [169], it is likely that inhibition of TRP channelmediated $\mathrm{Ca}^{2+}$ in cardiac myocytes not only produces a protective effect on myocytes, but also may attenuate replacement fibrosis triggered by cardiomyocyte death. Given the unique features and diversified activation mechanisms of TRP channels, future studies may uncover more important functions of TRP channels in cardiac fibroblasts and fibrotic heart diseases.

\section{CONCLUSIONS}

Fibrosis is a hallmark feature of a variety of heart diseases. A number of signaling pathways, bioactive molecules, and cell types are involved in cardiac fibrogenesis cascades. Cardiac 
fibroblasts have been demonstrated as the final common effector for producing and regulating fibrosis. The importance of $\mathrm{Ca}^{2+}$ signaling in regulating fibroblast function has long been recognized. However, the molecules responsible for $\mathrm{Ca}^{2+}$ signaling in cardiac fibroblasts are just being revealed. TRP channels with their unique features have emerged as the most important ion channels in mediating $\mathrm{Ca}^{2+}$ signals in cardiac fibroblasts. In the past couple of years, TRPC 3 and TRPM7 have been demonstrated to be potential novel targets for cardiac fibrogenesis. Future studies will uncover more mechanistic insights and therapeutic potentials of TRP channels in fibrosis associated heart disease.

\section{Acknowledgments}

This work was generously supported by the National Institutes of Health, National Heart, Lung and Blood Institute (NHLBI) (www.nhlbi.nih.gov, grant number 2R01HL07 8960) and American Heart Association (AHA, 12GRNT12050683) to LY.

\section{References}

1. Weber KT, Sun Y, Diez J. Fibrosis: A Living Tissue and the Infarcted Heart. J Am Coll Cardiol. 2008; 52(24):2029-2031. [PubMed: 19055995]

2. de Bakker JM, van Capelle FJ, Janse MJ, Tasseron S, Vermeulen JT, de Jonge N, Lahpor JR. Fractionated electrograms in dilated cardiomyopathy: origin and relation to abnormal conduction. $\mathrm{J}$ Am Coll Cardiol. 1996; 27(5):1071-8. [PubMed: 8609323]

3. Burstein B, Nattel S. Atrial Fibrosis: Mechanisms and Clinical Relevance in Atrial Fibrillation. Journal of the American College of Cardiology. 2008; 51(8):802-809. [PubMed: 18294563]

4. Yue L, Xie J, Nattel S. Molecular determinants of cardiac fibroblast electrical function and therapeutic implications for atrial fibrillation. Cardiovasc Res. 2011; 89(4):744-53. [PubMed: 20962103]

5. Khan R, Sheppard R. Fibrosis in heart disease: understanding the role of transforming growth factor-beta in cardiomyopathy, valvular disease and arrhythmia. Immunology. 2006; 118(1):10-24. [PubMed: 16630019]

6. Weber KT. Are myocardial fibrosis and diastolic dysfunction reversible in hypertensive heart disease? Congest Heart Fail. 2005; 11(6):322-4. [PubMed: 16330908]

7. Kania G, Blyszczuk P, Eriksson U. Mechanisms of cardiac fibrosis in inflammatory heart disease. Trends Cardiovasc Med. 2009; 19(8):247-52. [PubMed: 20447565]

8. Biernacka A, Frangogiannis NG. Aging and Cardiac Fibrosis. Aging Dis. 2(2):158-173. [PubMed: 21837283]

9. Anderson KR, Sutton MG, Lie JT. Histopathological types of cardiac fibrosis in myocardial disease. J Pathol. 1979; 128(2):79-85. [PubMed: 572867]

10. Weber KT, Pick R, Jalil JE, Janicki JS, Carroll EP. Patterns of myocardial fibrosis. J Mol Cell Cardiol. 1989; 21 (Suppl 5):121-31. [PubMed: 2534137]

11. Isoyama S, Nitta-Komatsubara Y. Acute and chronic adaptation to hemodynamic overload and ischemia in the aged heart. Heart Fail Rev. 2002; (1):63-9. [PubMed: 11790923]

12. Swynghedauw B. Molecular mechanisms of myocardial remodeling. Physiol Rev. 1999; 79(1): 215-62. [PubMed: 9922372]

13. Weber KT, Sun Y, Tyagi SC, Cleutjens JP. Collagen network of the myocardium: function, structural remodeling and regulatory mechanisms. J Mol Cell Cardiol. 1994; 26(3):279-92. [PubMed: 8028011]

14. Powell DW, Mifflin RC, Valentich JD, Crowe SE, Saada JI, West AB. MyofibroblastsI Paracrine cells important in health and disease. Am J Physiol. 1999; 277(1 Pt 1):C1-9. [PubMed: 10409103]

15. Tomasek JJ, Gabbiani G, Hinz B, Chaponnier C, Brown RA. Myofibroblasts and mechanoregulation of connective tissue remodelling. Nat Rev Mol Cell Biol. 2002; 3(5):349-63. [PubMed: 11988769]

16. Sun Y, Weber KT. Infarct scar: a dynamic tissue. Cardiovasc Res. 2000; 46(2):250-6. [PubMed: 10773228] 
17. Petrov VV, Fagard RH, Lijnen PJ. Stimulation of Collagen Production by Transforming Growth Factor-\{beta\}1 During Differentiation of Cardiac Fibroblasts to Myofibroblasts. Hypertension. 2002; 39(2):258-263. [PubMed: 11847194]

18. Porter KE, Turner NA. Cardiac fibroblasts: at the heart of myocardial remodeling. Pharmacol Ther. 2009; 123(2):255-78. [PubMed: 19460403]

19. Leask A. Potential therapeutic targets for cardiac fibrosis: TGFbeta, angiotensin, endothelin, CCN2, and PDGF, partners in fibroblast activation. Circ Res. 2012; 106(11):1675-80. [PubMed: 20538689]

20. Weber, K. Cardiac interstitium. In: Poole-Wilson, P., et al., editors. Heart Failure. Churchill Livingstone; New York, NY: 1997. p. 13-31.

21. Beltrami CA, Finato N, Rocco M, Feruglio GA, Puricelli C, Cigola E, Quaini F, Sonnenblick EH, Olivetti G, Anversa P. Structural basis of end-stage failure in ischemic cardiomyopathy in humans. Circulation. 1994; 89(1):151-163. [PubMed: 8281642]

22. Sun Y, Kiani MF, Postlethwaite AE, Weber KT. Infarct scar as living tissue. Basic Res Cardiol. 2002; 97(5):343-7. [PubMed: 12200633]

23. Brooks A, Schinde V, Bateman AC, Gallagher PJ. Interstitial fibrosis in the dilated non-ischaemic myocardium. Heart. 2003; 89(10):1255-6. [PubMed: 12975439]

24. Marijianowski MM, Teeling P, Mann J, Becker AE. Dilated cardiomyopathy is associated with an increase in the type I/type III collagen ratio: a quantitative assessment. J Am Coll Cardiol. 1995; 25(6):1263-72. [PubMed: 7722119]

25. Sanderson JE, Lai KB, Shum IO, Wei S, Chow LT. Transforming growth factor-beta(1) expression in dilated cardiomyopathy. Heart. 2001; 86(6):701-8. [PubMed: 11711472]

26. Kuhl U, Noutsias M, Schultheiss HP. Immunohistochemistry in dilated cardiomyopathy. Eur Heart J. 1995; 16(Suppl O):100-6. [PubMed: 8682073]

27. Dixon IM, Hao J, Reid NL, Roth JC. Effect of chronic AT(1) receptor blockade on cardiac Smad overexpression in hereditary cardiomyopathic hamsters. Cardiovasc Res. 2000; 46(2):286-97. [PubMed: 10773233]

28. Kostin S, Klein G, Szalay Z, Hein S, Bauer EP, Schaper J. Structural correlate of atrial fibrillation in human patients. Cardiovasc Res. 2002; 54(2):361-79. [PubMed: 12062341]

29. Benjamin EJ, Chen P-S, Bild DE, Mascette AM, Albert CM, Alonso A, Calkins H, Connolly SJ, Curtis AB, Darbar D, Ellinor PT, Go AS, Goldschlager NF, Heckbert SR, Jalife J, Kerr CR, Levy D, Lloyd-Jones DM, Massie BM, Nattel S, Olgin JE, Packer DL, Po SS, Tsang TSM, Van Wagoner DR, Waldo AL, Wyse DG. Prevention of Atrial Fibrillation: Report From a National Heart, Lung, and Blood Institute Workshop. Circulation. 2009; 119(4):606-618. [PubMed: 19188521]

30. Boldt A, Wetzel U, Lauschke J, Weigl J, Gummert J, Hindricks G, Kottkamp H, Dhein S. Fibrosis in left atrial tissue of patients with atrial fibrillation with and without underlying mitral valve disease. Heart. 2004; 90(4):400-5. [PubMed: 15020515]

31. Xu J, Cui G, Esmailian F, Plunkett M, Marelli D, Ardehali A, Odim J, Laks H, Sen L. Atrial extracellular matrix remodeling and the maintenance of atrial fibrillation. Circulation. 2004; 109(3):363-8. [PubMed: 14732752]

32. Frustaci A, Chimenti C, Bellocci F, Morgante E, Russo MA, Maseri A. Histological substrate of atrial biopsies in patients with lone atrial fibrillation. Circulation. 1997; 96(4):1180-4. [PubMed: 9286947]

33. Nakajima H, Nakajima HO, Salcher O, Dittie AS, Dembowsky K, Jing S, Field LJ. 2000, Atrial but not ventricular fibrosis in mice expressing a mutant transforming growth factor-beta(1) transgene in the heart. Circ Res. 2000; 86(5):571-9. [PubMed: 10720419]

34. Verheule S, Sato T, Everett Tt, Engle SK, Otten D, Rubartvon der Lohe M, Nakajima HO, Nakajima H, Field LJ, Olgin JE. Increased vulnerability to atrial fibrillation in transgenic mice with selective atrial fibrosis caused by overexpression of TGF-beta1. Circ Res. 2004; 94(11): 1458-65. [PubMed: 15117823]

35. Cha TJ, Ehrlich JR, Zhang L, Shi YF, Tardif JC, Leung TK, Nattel S. Dissociation between ionic remodeling and ability to sustain atrial fibrillation during recovery from experimental congestive heart failure. Circulation. 2004; 109(3):412-8. [PubMed: 14718405] 
36. Shinagawa K, Shi YF, Tardif JC, Leung TK, Nattel S. Dynamic nature of atrial fibrillation substrate during development and reversal of heart failure in dogs. Circulation. 2002; 105(22): 2672-8. [PubMed: 12045175]

37. Pearlman ES, Weber KT, Janicki JS, Pietra GG, Fishman AP. Muscle fiber orientation and connective tissue content in the hypertrophied human heart. Lab Invest. 1992; 46(2):158-64. [PubMed: 6460896]

38. Rossi MA. Pathologic fibrosis and connective tissue matrix in left ventricular hypertrophy due to chronic arterial hypertension in humans. J Hypertens. 1998; 16(7):1031-41. [PubMed: 9794745]

39. Brilla CG, Janicki JS, Weber KT. Impaired diastolic function, coronary reserve in genetic hypertension. Role of interstitial fibrosis and medial thickening of intramyocardial coronary arteries. Circ Res. 1991; 69(1):107-15. [PubMed: 1647274]

40. Diez J, Querejeta R, Lopez B, Gonzalez A, Larman M, Martinez Ubago JL. Losartan-dependent regression of myocardial fibrosis is associated with reduction of left ventricular chamber stiffness in hypertensive patients. Circulation. 2002; 105(21):2512-7. [PubMed: 12034658]

41. Sugihara N, Genda A, Shimizu M, Suematu T, Kita Y, Horita Y, Takeda R. Quantitation of myocardial fibrosis and its relation to function in essential hypertension and hypertrophic cardiomyopathy. Clin Cardiol. 1988; 11(11):771-8. [PubMed: 3233804]

42. Sugihara N, Genda A, Shimizu M, Suematsu T, Kita Y, Minamoto M, Kawagoshi H, Umeda K, Chin S, Takeda R. Diastolic dysfunction and its relation to myocardial fibrosis in essential hypertension. J Cardiol. 18(2):353-61. [PubMed: 2977793]

43. Brilla CG, Matsubara L, Weber KT. Advanced hypertensive heart disease in spontaneously hypertensive rats. Lisinopril-mediated regression of myocardial fibrosis. Hypertension. 1996; 28(2):269-75. [PubMed: 8707393]

44. Brilla CG, Janicki JS, Weber KT. Cardioreparative effects of lisinopril in rats with genetic hypertension and left ventricular hypertrophy. Circulation. 1991; 83(5):1771-9. [PubMed: 1850668]

45. Sangaralingham SJ, Huntley BK, Martin FL, McKie PM, Bellavia D, Ichiki T, Harders GE, Chen HH, Burnett JC. The Aging Heart, Myocardial Fibrosis, and its Relationship to Circulating C-Type Natriuretic Peptide. Hypertension. 2011; 57(2):201-207. [PubMed: 21189408]

46. Aharinejad S, Krenn K, Paulus P, Schafer R, Zuckermann A, Grimm M, Abraham D. Differential role of TGF-beta1/bFGF and ET-1 in graft fibrosis in heart failure patients. Am J Transplant. 2005; 5(9):2185-92. [PubMed: 16095497]

47. Weber KT, Brilla CG, Janicki JS. Myocardial fibrosis: functional significance and regulatory factors. Cardiovasc Res. 1993; 27(3):341-8. [PubMed: 8490934]

48. Hanatani A, Yoshiyama M, Kim S, Omura T, Toda I, Akioka K, Teragaki M, Takeuchi K, Iwao H, Takeda T. Inhibition by angiotensin II type 1 receptor antagonist of cardiac phenotypic modulation after myocardial infarction. J Mol Cell Cardiol. 1995; 27(9):1905-14. [PubMed: 8523451]

49. Urata H, Boehm KD, Philip A, Kinoshita A, Gabrovsek J, Bumpus FM, Husain A. Cellular localization and regional distribution of an angiotensin II-forming chymase in the heart. J Clin Invest. 1993; 91(4):1269-81. [PubMed: 7682566]

50. Lijnen PJ, Piccart Y, Coenen T, Prihadi JS. Angiotensin II-induced mitochondrial reactive oxygen species and peroxire-doxin-3 expression in cardiac fibroblasts. J Hypertens. 2012; 30(10):198691. [PubMed: 22828084]

51. Lijnen PJ, van Pelt JF, Fagard RH. Stimulation of reactive oxygen species and collagen synthesis by angiotensin II in cardiac fibroblasts. Cardiovasc Ther. 2012; 30(1):1-8.

52. Clancy RM, Zheng P, O’Mahony M, Izmirly P, Zavadil J, Gardner L, Buyon JP. Role of hypoxia and cAMP in the transdifferentiation of human fetal cardiac fibroblasts: implications for progression to scarring in autoimmune-associated congenital heart block. Arthritis Rheum. 2007; 56(12):4120-31. [PubMed: 18050204]

53. Aragno M, Mastrocola R, Alloatti G, Vercellinatto I, Bardini P, Geuna S, Catalano MG, Danni O, Boccuzzi G. 2008, Oxidative Stress Triggers Cardiac Fibrosis in the Heart of Diabetic Rats. Endocrinology. 2008; 149(1):380-388. [PubMed: 17901230]

54. Weber KT, Brilla CG, Campbell SE, Guarda E, Zhou G, Sriram K. Myocardial fibrosis: role of angiotensin II and aldosterone. Basic Res Cardiol. 1993; 88(Suppl 1):107-24. [PubMed: 8395170] 
55. Holtz J. Pathophysiology of heart failure and the renin-angiotensin-system. Basic Res Cardiol. 1993; 88:183-201. [PubMed: 8357333]

56. Weber KT, Sun Y, Katwa LC, Cleutjens JP. Tissue repair and angiotensin II generated at sites of healing. Basic Res Cardiol. 1997; 92(2):75-8. [PubMed: 9166984]

57. Schultz Jel J, Witt SA, Glascock BJ, Nieman ML, Reiser PJ, Nix SL, Kimball TR, Doetschman T. TGF-beta1 mediates the hypertrophic cardiomyocyte growth induced by angiotensin II. J Clin Invest. 2002; 109(6):787-96. [PubMed: 11901187]

58. Campbell SE, Katwa LC. Angiotensin II stimulated expression of transforming growth factorbeta1 in cardiac fibroblasts and myofibroblasts. J Mol Cell Cardiol. 1997; 29(7):1947-58. [PubMed: 9236148]

59. Martin MM, Buckenberger JA, Jiang J, Malana GE, Knoell DL, Feldman DS, Elton TS. TGFbeta1 stimulates human AT1 receptor expression in lung fibroblasts by cross talk between the Smad, p38 MAPK, JNK, and PI3K signaling pathways. Am J Physiol Lung Cell Mol Physiol. 2007; 293(3):L790-9. [PubMed: 17601799]

60. Tharaux P-L, Chatziantoniou C, Fakhouri F, Dussaule J-C. Angiotensin II Activates Collagen I Gene Through a Mechanism Involving the MAP/ER Kinase Pathway. Hypertension. 36(3):330 336. [PubMed: 10988260]

61. Massague J. The transforming growth factor-beta family. Annu Rev Cell Biol. 1990; 6:597-641. [PubMed: 2177343]

62. Agrotis A, Kalinina N, Bobik A. Transforming growth factor-beta, cell signaling and cardiovascular disorders. Curr Vasc Pharmacol. 2005; 3(1):55-61. [PubMed: 15638782]

63. Lijnen PJ, Petrov VV, Fagard RH. Induction of cardiac fibrosis by transforming growth factorbeta(1). Mol Genet Metab. 2000; 71(1-2):418-35. [PubMed: 11001836]

64. Pedrozo HA, Schwartz Z, Gomez R, Ornoy A, Xin-Sheng W, Dallas SL, Bonewald LF, Dean DD, Boyan BD. Growth plate chondrocytes store latent transforming growth factor (TGF)-beta 1 in their matrix through latent TGF-beta 1 binding protein-1. J Cell Physiol. 1998; 177(2):343-54. [PubMed: 9766531]

65. Brand T, Schneider MD. The TGF beta superfamily in myocardium: ligands, receptors, transduction, and function. J Mol Cell Cardiol. 1995; 27(1):5-18. [PubMed: 7760369]

66. de Boer RA, Pokharel S, Flesch M, van Kampen DA, Suurmeijer AJ, Boomsma F, van Gilst WH, van Veldhuisen DJ, Pinto YM. Extracellular signal regulated kinase and SMAD signaling both mediate the angiotensin II driven progression towards overt heart failure in homozygous TGR(mRen2)27. J Mol Med (Berl). 2004; 82(10):678-87. [PubMed: 15322702]

67. Leask A, Abraham DJ. TGF-beta signaling and the fibrotic response. FASEB J. 2004; 18(7):81627. [PubMed: 15117886]

68. Santander C, Brandan E. Betaglycan induces TGF-beta signaling in a ligand-independent manner, through activation of the p38 pathway. Cell Signal. 2006; 18(9):1482-91. [PubMed: 16413747]

69. Liu S, Xu SW, Kennedy L, Pala D, Chen Y, Eastwood M, Carter DE, Black CM, Abraham DJ, Leask A. FAK is required for TGFbeta-induced JNK phosphorylation in fibroblasts: implications for acquisition of a matrix-remodeling phenotype. Mol Biol Cell. 2007; 18(6):2169-78. [PubMed: 17409352]

70. Thannickal VJ, Lee DY, White ES, Cui Z, Larios JM, Chacon R, Horowitz JC, Day RM, Thomas PE. Myofibroblast differentiation by transforming growth factor-betal is dependent on cell adhesion and integrin signaling via focal adhesion kinase. J Biol Chem. 2003; 278(14):12384-9. [PubMed: 12531888]

71. Sano Y, Harada J, Tashiro S, Gotoh-Mandeville R, Maekawa T, Ishii S. ATF-2 is a common nuclear target of Smad and TAK1 pathways in transforming growth factor-beta signaling. J Biol Chem. 1999; 274(13):8949-57. [PubMed: 10085140]

72. Zhang D, Gaussin V, Taffet GE, Belaguli NS, Yamada M, Schwartz RJ, Michael LH, Overbeek PA, Schneider MD. 2000, TAK1 is activated in the myocardium after pressure overload and is sufficient to provoke heart failure in transgenic mice. Nat Med. 2000; 6(5):556-63. [PubMed: 10802712]

73. Small EM, Thatcher JE, Sutherland LB, Kinoshita H, Gerard RD, Richardson JA, Dimaio JM, Sadek H, Kuwahara K, Olson EN. Myocardin-related transcription factor-a controls myofibroblast 
activation and fibrosis in response to myocardial infarction. Circ Res. 2010; 107(2):294-304. [PubMed: 20558820]

74. Kagiyama S, Matsumura K, Goto K, Otsubo T, Iida M. Role of Rho kinase and oxidative stress in cardiac fibrosis induced by aldosterone and salt in angiotensin type 1a receptor knockout mice. Regul Pept. 2010; 160(1-3):133-9. [PubMed: 19969025]

75. Hein S, Arnon E, Kostin S, Schonburg M, Elsasser A, Polyakova V, Bauer EP, Klovekorn WP, Schaper J. Progression from compensated hypertrophy to failure in the pressure-overloaded human heart: structural deterioration and compensatory mechanisms. Circulation. 2002; 107(7):984-91. [PubMed: 12600911]

76. Shimizu N, Yoshiyama M, Takeuchi K, Hanatani A, Kim S, Omura T, Iwao H, Yoshikawa J. Doppler echocardiographic assessment and cardiac gene expression analysis of the left ventricle in myocardial infarcted rats. Jpn Circ J. 1998; 62(6):436-42. [PubMed: 9652320]

77. Clozel M, Salloukh H. Role of endothelin in fibrosis and anti-fibrotic potential of bosentan. Ann Med. 2005; 37(1):2-12. [PubMed: 15902842]

78. Teder P, Noble PW. A cytokine reborn? Endothelin-1 in pulmonary inflammation and fibrosis. Am J Respir Cell Mol Biol. 2000; 23(1):7-10. [PubMed: 10873147]

79. Rubanyi GM, Polokoff MA. Endothelins: molecular biology, biochemistry, pharmacology, physiology, and pathophysiology. Pharmacol Rev. 1994; 46(3):325-415. [PubMed: 7831383]

80. Shi-wen X, Kennedy L, Renzoni EA, Bou-Gharios G, du Bois RM, Black CM, Denton CP, Abraham DJ, Leask A. Endothelin is a downstream mediator of profibrotic responses to transforming growth factor beta in human lung fibroblasts. Arthritis Rheum. 2007; 56(12):418994. [PubMed: 18050250]

81. Shephard P, Hinz B, Smola-Hess S, Meister JJ, Krieg T, Smola H. Dissecting the roles of endothelin, TGF-beta and GM-CSF on myofibroblast differentiation by keratinocytes. Thromb Haemost. 2004; 92(2):262-74. [PubMed: 15269821]

82. Leask A, Abraham DJ. All in the CCN family: essential matricellular signaling modulators emerge from the bunker. J Cell Sci. 2006; 119(23):4803-10. [PubMed: 17130294]

83. Creemers EE, Pinto YM. Molecular mechanisms that control interstitial fibrosis in the pressureoverloaded heart. Cardiovasc Res. 2011; 89(2):265-72. [PubMed: 20880837]

84. Chen MM, Lam A, Abraham JA, Schreiner GF, Joly AH. CTGF expression is induced by TGFbeta in cardiac fibroblasts and cardiac myocytes: a potential role in heart fibrosis. J Mol Cell Cardiol. 2000; 32(10):1805-19. [PubMed: 11013125]

85. Perrot A, Hussein S, Ruppert V, Schmidt HH, Wehnert MS, Duong NT, Posch MG, Panek A, Dietz R, Kindermann I, Bohm M, Michalewska-Wludarczyk A, Richter A, Maisch B, Pankuweit $\mathrm{S}$, Ozcelik C. Identification of mutational hot spots in LMNA encoding lamin A/C in patients with familial dilated cardiomyopathy. Basic Res Cardiol. 2009; 104(1):90-9. [PubMed: 18795223]

86. Leask A. Targeting the TGFbeta, endothelin-1 and CCN2 axis to combat fibrosis in scleroderma. Cell Signal. 2008; 20(8):1409-14. [PubMed: 18296024]

87. Shi-Wen X, Leask A, Abraham D. Regulation and function of connective tissue growth factor/ CCN2 in tissue repair, scarring and fibrosis. Cytokine Growth Factor Rev. 2008; 19(2):133-44. [PubMed: 18358427]

88. Hayata N, Fujio Y, Yamamoto Y, Iwakura T, Obana Takai M, Mohri T, Nonen S, Maeda M, Azuma J. Connective tissue growth factor induces cardiac hypertrophy through Akt signaling. Biochem Biophys Res Commun. 2008; 370(2):274-8. [PubMed: 18375200]

89. Kennedy L, Liu S, Shi-Wen X, Chen Y, Eastwood M, Sabetkar M, Carter DE, Lyons KM, Black $\mathrm{CM}$, Abraham DJ, Leask A. CCN2 is necessary for the function of mouse embryonic fibroblasts. Exp Cell Res. 313(5):952-64. [PubMed: 17239853]

90. Panek AN, Posch MG, Alenina N, Ghadge SK, Erdmann B, Popova E, Perrot A, Geier C, Dietz R, Morano I, Bader M, Ozcelik C. Connective tissue growth factor overexpression in cardiomyocytes promotes cardiac hypertrophy and protection against pressure overload. PLoS One. 2009; 4(8): 6743.

91. Bonner JC. Regulation of PDGF and its receptors in fibrotic diseases. Cytokine Growth Factor Rev. 2004; 15(4):255-73. [PubMed: 15207816] 
92. Trengove NJ, Bielefeldt-Ohmann H, Stacey MC. Mitogenic activity and cytokine levels in nonhealing and healing chronic leg ulcers. Wound Repair Regen. 2000; 8(1):13-25. [PubMed: 10760211]

93. Heldin CH, Westermark B. Mechanism of action and in vivo role of platelet-derived growth factor. Physiol Rev. 1999; 79(4):1283-316. [PubMed: 10508235]

94. Uutela M, Wirzenius M, Paavonen K, Rajantie I, He Y, Karpanen T, Lohela M, Wiig H, Salven P, Pajusola K, Eriksson U, Alitalo K. PDGF-D induces macrophage recruitment, increased interstitial pressure, and blood vessel maturation during angiogenesis. Blood. 2004; 104(10):3198-204. [PubMed: 15271796]

95. Ihn H, Yamane K, Asano Y, Jinnin M, Tamaki K. Constitutively phosphorylated Smad3 interacts with Sp1 and p300 in scleroderma fibroblasts. Rheumatology (Oxford). 2006; 45(2):157-65. [PubMed: 16319104]

96. Jinnin M, Ihn H, Mimura Y, Asano Y, Yamane K, Tamaki K. Regulation of fibrogenic/fibrolytic genes by platelet-derived growth factor $\mathrm{C}$, a novel growth factor, in human dermal fibroblasts. $\mathrm{J}$ Cell Physiol. 2005; 202(2):510-7. [PubMed: 15389578]

97. Ponten A, Folestad EB, Pietras K, Eriksson U. Platelet-derived growth factor D induces cardiac fibrosis and proliferation of vascular smooth muscle cells in heart-specific transgenic mice. Circ Res. 2005; 97(10):1036-45. [PubMed: 16224065]

98. Ponten A, Li X, Thoren P, Aase K, Sjoblom T, Ostman A, Eriksson U. Transgenic overexpression of platelet-derived growth factor- $\mathrm{C}$ in the mouse heart induces cardiac fibrosis, hypertrophy, and dilated cardiomyopathy. Am J Pathol. 2003; 163(2):673-82. [PubMed: 12875986]

99. Liao CH, Akazawa H, Tamagawa M, Ito K, Yasuda N, Kudo Y, Yamamoto R, Ozasa Y, Fujimoto M, Wang P, Nakauchi H, Nakaya H, Komuro I. Cardiac mast cells cause atrial fibrillation through PDGF-A-mediated fibrosis in pressure-overloaded mouse hearts. J Clin Invest. 2010; 120(1):24253. [PubMed: 20038802]

100. Burstein B, Libby E, Calderone A, Nattel S. Differential Behaviors of Atrial Versus Ventricular Fibroblasts: A Potential Role for Platelet-Derived Growth Factor in Atrial-Ventricular Remodeling Differences. Circulation. 2008; 117(13):1630-1641. [PubMed: 18347210]

101. Snider P, Standley KN, Wang J, Azhar M, Doetschman T, Conway SJ. Origin of Cardiac Fibroblasts and the Role of Periostin. Circulation Research. 2009; 105(10):934-947. [PubMed: 19893021]

102. Krenning G, Zeisberg EM, Kalluri R. The origin of fibroblasts and mechanism of cardiac fibrosis. J Cell Physiol. 2010; 225(3):631-7. [PubMed: 20635395]

103. Kamkin A, Kiseleva I, Wagner KD, Pylaev A, Leiterer KP, Theres H, Scholz H, Gunther J, Isenberg G. A possible role for atrial fibroblasts in postinfarction bradycardia. Am J Physiol Heart Circ Physiol. 2002; 282(3):842-9.

104. Kamkin A, Kiseleva I, Wagner KD, Lammerich A, Bohm J, Persson PB, Gunther J. Mechanically induced potentials in fibroblasts from human right atrium. Exp Physiol. 1999; 84(2):347-56. [PubMed: 10226175]

105. Kamkin A, Kiseleva I, Isenberg G. Activation and inactivation of a non-selective cation conductance by local mechanical deformation of acutely isolated cardiac fibroblasts. Cardiovasc Res. 2003; 57(3):793-803. [PubMed: 12618241]

106. Chilton L, Ohya S, Freed D, George E, Drobic V, Shibukawa Y, MacCannell KA, Imaizumi Y, Clark RB, Dixon IMC, Giles WR. K+ currents regulate the resting membrane M., potential, proliferation, and contractile responses in ventricular fibroblasts and myofibroblasts. Am J Physiol Heart Circ Physiol. 2005; 288(6):2931-2939.

107. Shibukawa Y, Chilton EL, Maccannell KA, Clark RB, Giles WR. K+ currents activated by depolarization in cardiac fibroblasts. Biophys J. 2005; 88(6):3924-35. [PubMed: 15764658]

108. Walsh KB, Zhang J. Neonatal rat cardiac fibroblasts express three types of voltage-gated K+ channels: regulation of a transient outward current by protein kinase C. Am J Physiol Heart Circ Physiol. 2008; 294(2):1010-1017.

109. Li GR, Sun HY, Chen JB, Zhou Y, Tse HF, Lau CP. Characterization of multiple ion channels in cultured human cardiac fibroblasts. PLoS One. 2009; 4(10):7307. 
110. Chatelier A, Mercier A, Tremblier B, Theriault O, Moubarak M, Benamer N, Corbi P, Bois P, Chahine M, Faivre JF. A distinct de novo expression of Nav1.5 sodium channels in human atrial fibroblasts differentiated into myofibroblasts. The Journal of Physiology. 2012; 590(17):43074319. [PubMed: 22802584]

111. Benamer N, Fares N, Bois P, Faivre JF. Electrophysiological and functional effects of sphingosine-1-phosphate in mouse ventricular fibroblasts. Biochem Biophys Res Commun. 2011; 408(1):6-11. [PubMed: 21420933]

112. Benamer N, Moha Ou Maati H, Demolombe S, Cantereau A, Delwail A, Bois P, Bescond J, Faivre JF. Molecular and functional characterization of a new potassium conductance in mouse ventricular fibroblasts. J Mol Cell Cardiol. 2009; 46(4):508-17. [PubMed: 19166858]

113. El Chemaly A, Guinamard R, Demion M, Fares N, Jebara V, Faivre JF, Bois P. A voltageactivated proton current in human cardiac fibroblasts. Biochem Biophys Res Commun. 2006; 340(2):512-6. [PubMed: 16376300]

114. He ML, Liu WJ, Sun HY, Wu W, Liu J, Tse HF, Lau CP, Li GR. Effects of ion channels on proliferation in cultured human cardiac fibroblasts. J Mol Cell Cardiol. 2011; 51(2):198-206. [PubMed: 21620856]

115. Berridge MJ, Bootman MD, Roderick HL. Calcium signalling: dynamics, homeostasis and remodelling. Nat Rev Mol Cell Biol. 2013; 4(7):517-29. [PubMed: 12838335]

116. Oh-hora M, Rao A. Calcium signaling in lymphocytes. Curr Opin Immunol. 2008; 20(3):250-8. [PubMed: 18515054]

117. Kiseleva I, Kamkin A, Kohl P, Lab MJ. Calcium and mechanically induced potentials in fibroblasts of rat atrium. Cardiovasc Res. 1996; 32(1):98-111. [PubMed: 8776407]

118. Kiseleva I, Kamkin A, Pylaev A, Kondratjev D, Leiterer KP, Theres H, Wagner KD, Persson PB, Gunther J. Electrophysiological properties of mechanosensitive atrial fibroblasts from chronic infarcted rat heart. J Mol Cell Cardiol. 1998; 30(6):1083-93. [PubMed: 9689583]

119. Kumaran C, Shivakumar K. Calcium- and superoxide anion-mediated mitogenic action of substance P on cardiac fibroblasts. Am J Physiol Heart Circ Physiol. 2002; 282(5):1855-62.

120. Shivakumar K, Kumaran C. L-type calcium channel blockers and EGTA enhance superoxide production in cardiac fibroblasts. J Mol Cell Cardiol. 2001; 33(2):373-7. [PubMed: 11162140]

121. Colston JT, Chandrasekar B, Freeman GL. A novel peroxide-induced calcium transient regulates interleukin-6 expression in cardiac-derived fibroblasts. J Biol Chem. 2002; 277(26):23477-83. [PubMed: 11983681]

122. Ramires FJ, Sun Y, Weber KT. Myocardial fibrosis associated with aldosterone or angiotensin II administration: attenuation by calcium channel blockade. J Mol Cell Cardiol. 1998; 30(3):47583. [PubMed: 9515025]

123. Chen JB, Tao R, Sun HY, Tse HF, Lau CP, Li GR. Multiple Ca2+ signaling pathways regulate intracellular Ca2+ activity in human cardiac fibroblasts. J Cell Physiol. 2010; 223(1):68-75. [PubMed: 20039269]

124. Montell C, Jones K, Hafen E, Rubin G. Rescue of the Drosophila phototransduction mutation trp by germline transformation. Science. 1985; 230(4729):1040-3. [PubMed: 3933112]

125. Montell C, Rubin GM. Molecular characterization of the Drosophila trp locus: a putative integral membrane protein required for phototransduction. Neuron. 1989; 2(4):1313-23. [PubMed: 2516726]

126. Clapham DE. TRP channels as cellular sensors. Nature. 2003; 426(6966):517-24. [PubMed: 14654832]

127. Montell C. The TRP superfamily of cation channels. Sci STKE. 2005; (272):1-24.

128. Nilius B, Vennekens R. From cardiac cation channels to the molecular dissection of the transient receptor potential channel TRPM4. Pf lugers Arch. 2006; 453(3):313-21.

129. Hofmann T, Obukhov AG, Schaefer M, Harteneck C, Gudermann T, Schultz G. Direct activation of human TRPC6 and TRPC3 channels by diacylglycerol. Nature. 1999; 397(6716):259-63. [PubMed: 9930701]

130. Hofmann T, Schaefer M, Schultz G, Gudermann T. Subunit composition of mammalian transient receptor potential channels in living cells. Proc Natl Acad Sci USA. 2002; 99(11):7461-6. [PubMed: 12032305] 
131. Dong XP, Wang X, Xu H. TRP channels of intracellular membranes. J Neurochem. 2010; 113(2): 313-28. [PubMed: 20132470]

132. Yue L, Peng JB, Hediger MA, Clapham DE. CaT1 manifests the pore properties of the calciumrelease-activated calcium channel. Nature. 2001; 410(6829):705-9. [PubMed: 11287959]

133. Nilius B, Vennekens R, Prenen J, Hoenderop JG, Droogmans G, Bindels RJ. The single pore residue Asp542 determines $\mathrm{Ca} 2+$ permeation and $\mathrm{Mg} 2+$ block of the epithelial $\mathrm{Ca} 2+$ channel. $\mathrm{J}$ Biol Chem. 2001; 276(2):1020-5. [PubMed: 11035011]

134. Nilius B, Owsianik G, Voets T. Transient receptor potential channels meet phosphoinositides. EMBO J. 2008; 27(21):2809-16. [PubMed: 18923420]

135. Dong XP, Shen D, Wang X, Dawson T, Li X, Zhang Q, Cheng X, Zhang Y, Weisman LS, Delling M, Xu H. PI(3,5)P(2) controls membrane trafficking by direct activation of mucolipin $\mathrm{Ca}(2+)$ release channels in the endolysosome. Nat Commun. 1:38. [PubMed: 20802798]

136. Xie J, Sun B, Du J, Yang W, Chen HC, Overton JD, Runnels LW, Yue L. Phosphatidylinositol 4,5-bisphosphate (PIP2) controls magnesium gatekeeper TRPM6 activity. Sci Rep. 2011; 1:12. [PubMed: 22355531]

137. Tóth B, Csanády L. Pore collapse underlies irreversible inactivation of TRPM2 cation channel currents. Proceedings of the National Academy of Sciences. 2012; 109(33):13440-13445.

138. Watanabe H, Murakami M, Ohba T, Takahashi Y, Ito H. TRP channel and cardiovascular disease. Pharmacol Ther. 2008; 118(3):337-51. [PubMed: 18508125]

139. Ju YK, Chu Y, Chaulet H, Lai D, Gervasio OL, Graham RM, Cannell MB, Allen DG. StoreOperated Ca2+ Influx and Expression of TRPC Genes in Mouse Sinoatrial Node. Circ Res. 2007; 100(11):1605-1614. [PubMed: 17478725]

140. Rose RA, Hatano N, Ohya S, Imaizumi Y, Giles WR. C-type natriuretic peptide activates a nonselective cation current in acutely isolated rat cardiac fibroblasts via natriuretic peptide $\mathrm{C}$ receptor-mediated signalling. J Physiol. 2007; 580(1):255-74. [PubMed: 17204501]

141. Nishida M, Onohara N, Sato Y, Suda R, Ogushi M, Tanabe S, Inoue R, Mori Y, Kurose H. Galpha12/13-mediated up-regulation of TRPC6 negatively regulates endothelin-1-induced cardiac myofibroblast formation and collagen synthesis through nuclear factor of activated $\mathrm{T}$ cells activation. J Biol Chem. 2007; 282(32):23117-28. [PubMed: 17533154]

142. Du J, Xie J, Zhang Z, Tsujikawa H, Fusco D, Silverman D, Liang B, Yue L. TRPM7-mediated $\mathrm{Ca} 2+$ signals confer fibrogenesis in human atrial fibrillation. Circ Res. 2010; 106(5):992-1003. [PubMed: 20075334]

143. Runnels LW, Yue L, Clapham DE. The TRPM7 channel is inactivated by PIP(2) hydrolysis. Nat Cell Biol. 2002; 4(5):329-36. [PubMed: 11941371]

144. Harada M, Luo X, Qi XY, Tadevosyan A, Maguy A, Ordog B, Ledoux J, Kato T, Naud P, Voigt N, Shi Y, Kamiya K, Murohara T, Kodama I, Tardif J-C, Schotten U, Van Wagoner DR, Dobrev D, Nattel S. TRPC3-Dependent Fibroblast Regulation in Atrial Fibrillation. Circulation. 2012; 126(17):2051-64. [PubMed: 22992321]

145. Takahashi K, Sakamoto K, Kimura J. Hypoxic stress induces transient receptor potential melastatin 2 (TRPM2) channel expression in adult rat cardiac fibroblasts. J Pharmacol Sci. 2012; 118(2):186-97. [PubMed: 22293297]

146. Hatano N, Itoh Y, Muraki K. Cardiac fibroblasts have functional TRPV4 activated by 4alphaphorbol 12,13-didecanoate. Life Sci. 2009; 85(23-26):808-14. [PubMed: 19879881]

147. Nadler MJ, Hermosura MC, Inabe K, Perraud AL, Zhu Q, Stokes AJ, Kurosaki T, Kinet JP, Penner R, Scharenberg AM, Fleig A. LTRPC7 is a Mg.ATP-regulated divalent cation channel required for cell viability. Nature. 2001; 411(6837):590-5. [PubMed: 11385574]

148. Runnels LW, Yue L, Clapham DE. TRP-PLIK, a bifunctional protein with kinase and ion channel activities. Science. 2001; 291(5506):1043-7. [PubMed: 11161216]

149. Yamaguchi H, Matsushita M, Nairn AC, Kuriyan J. Crystal structure of the atypical protein kinase domain of a TRP channel with phosphotransferase activity. Mol Cell. 2001; 7(5):1047-57. [PubMed: 11389851]

150. Jiang J, Li M, Yue L. Potentiation of TRPM7 Inward Currents by Protons. J Gen Physiol. 2005; 126(2):137-50. [PubMed: 16009728] 
151. Li M, Du J, Jiang J, Ratzan W, Su L-T, Runnels LW, Yue L. Molecular Determinants of Mg2+. Ca2+ Permeability. pH Sensitivity in TRPM6, TRPM7J. Biol Chem. 2007; 282(35):2581725830 .

152. Jin J, Desai BN, Navarro B, Donovan A, Andrews NC, Clapham DE. Deletion of Trpm7 disrupts embryonic development and thymopoiesis without altering $\mathrm{Mg} 2+$ homeostasis. Science. 2008; 322(5902):756-60. [PubMed: 18974357]

153. Ryazanova LV, Rondon LJ, Zierler S, Hu Z, Galli J, Yamaguchi TP, Mazur A, Fleig A, Ryazanov AG. TRPM7 is essential for $\mathrm{Mg}(2+)$ homeostasis in mammals. Nat Commun. 2010; 1:109. [PubMed: 21045827]

154. Jin J, Wu L-J, Jun J, Cheng X, Xu H, Andrews NC, Clapham DE. The channel kinase, TRPM7, is required for early embryonic development. Proceedings of the National Academy of Sciences. 2011

155. Liu W, Su LT, Khadka DK, Mezzacappa C, Komiya Y, Sato A, Habas R, Runnels LW. TRPM7 regulates gastrulation during vertebrate embryogenesis. Dev Biol. 2011; 350(2):348-57. [PubMed: 21145885]

156. Aarts M, Iihara K, Wei WL, Xiong ZG, Arundine M, Cerwinski W, MacDonald JF, Tymianski M. A key role for TRPM7 channels in anoxic neuronal death. Cell. 2003; 115(7):863-77. [PubMed: 14697204]

157. Sun HS, Jackson MF, Martin LJ, Jansen K, Teves L, Cui H, Kiyonaka S, Mori Y, Jones M, Forder JP, Golde TE, Orser BA, Macdonald JF, Tymianski M. Suppression of hippocampal TRPM7 protein prevents delayed neuronal death in brain ischemia. Nat Neurosci. 2009; 12(10): 1300-7. [PubMed: 19734892]

158. Schmitz C, Perraud AL, Johnson CO, Inabe K, Smith MK, Penner R, Kurosaki T, Fleig A, Scharenberg AM. Regulation of vertebrate cellular Mg2+ homeostasis by TRPM7. Cell. 2003; 114(2):191-200. [PubMed: 12887921]

159. Desai BN, Krapivinsky G, Navarro B, Krapivinsky L, Carter BC, Febvay S, Delling M, Penumaka A, Ramsey IS, Manasian Y, Clapham DE. Cleavage of TRPM7 releases the kinase domain from the ion channel and regulates its participation in Fas-induced apoptosis. Dev Cell. 2012; 22(6):1149-62. [PubMed: 22698280]

160. Wei C, Wang X, Chen M, Ouyang K, Song LSH. Calcium flickers steer cell migration. Nature. 2009; 457(7231):901-5. [PubMed: 19118385]

161. Middelbeek J, Kuipers AJ, Henneman L, Visser D, Eidhof I, van Horssen R, Wieringa B, Canisius SV, Zwart W, Wessels LF, Sweep FC, Bult P, Span PN, van Leeuwen FN, Jalink K. TRPM7 Is Required for Breast Tumor Cell Metastasis. Cancer Res. 2012

162. Bates-Withers C, Sah R, Clapham DE. TRPM7, the $\mathrm{Mg}(2+)$ inhibited channel and kinase. Adv Exp Med Biol. 704:173-83. [PubMed: 21290295]

163. Sahni J, Tamura R, Sweet IR, Scharenberg AM. TRPM7 regulates quiescent/proliferative metabolic transitions in lymphocytes. Cell Cycle. 2010; 9(17):3565-74. [PubMed: 20724843]

164. McNeill MS, Paulsen J, Bonde G, Burnight E, Hsu MY, Cornell RA. Cell death of melanophores in zebrafish trpm7 mutant embryos depends on melanin synthesis. J Invest Dermatol. 2007; 127(8):2020-30. [PubMed: 17290233]

165. Elizondo MR, Arduini BL, Paulsen J, MacDonald EL, Sabel JL, Henion PD, Cornell RA, Parichy DM. Defective skeletogenesis with kidney stone formation in dwarf zebrafish mutant for trpm7. Curr Biol. 2005; 15(7):667-71. [PubMed: 15823540]

166. Zhang YH, Sun HY, Chen KH, Du XL, Liu B, Cheng LC, Li X, Jin MW, Li GR. Evidence for functional expression of TRPM7 channels in human atrial myocytes. Basic Res Cardiol. 2012; 107(5):282. [PubMed: 22802050]

167. Nishida M, Kurose H. Roles of TRP channels in the development of cardiac hypertrophy. Naunyn Schmiedebergs Arch Pharmacol. 2008; 378(4):395-406. [PubMed: 18600314]

168. Satoh S, Tanaka H, Ueda Y, Oyama J, Sugano M, Sumimoto H, Mori Y, Makino N. Transient receptor potential (TRP) protein 7 acts as a $\mathrm{G}$ protein-activated $\mathrm{Ca} 2+$ channel mediating angiotensin II-induced myocardial apoptosis. Mol Cell Biochem. 2007; 294(1-2):205-15. [PubMed: 16838106] 
169. Eder P, Molkentin JD. TRPC channels as effectors of cardiac hypertrophy. Circ Res. 2011; 108(2):265-72. [PubMed: 21252153]

170. Kuwahara K, Wang Y, McAnally J, Richardson JA, Bassel-Duby R, Hill JA, Olson EN. TRPC6 fulfills a calcineurin signaling circuit during pathologic cardiac remodeling. J Clin Invest. 2006; 116(12):3114-26. [PubMed: 17099778]

171. Wu X, Eder P, Chang B, Molkentin JD. 2010, TRPC channels are necessary mediators of pathologic cardiac hypertrophy. Proceedings of the National Academy of Sciences. 2010; 107(15):7000-7005.

172. Onohara N, Nishida M, Inoue R, Kobayashi H, Sumimoto H, Sato Y, Mori Y, Nagao T, Kurose H. TRPC3 and TRPC6 are essential for angiotensin II-induced cardiac hypertrophy. EMBO J. 2006; 25(22):5305-16. [PubMed: 17082763]

173. Heineke J, Molkentin JD. Regulation of cardiac hypertrophy by intracellular signalling pathways. Nat Rev Mol Cell Biol. 2006; 7(8):589-600. [PubMed: 16936699]

174. Shiroshita-Takeshita A, Brundel BJ, Burstein B, Leung TK, Mitamura H, Ogawa S, Nattel S. Effects of simvastatin on the development of the atrial fibrillation substrate in dogs with congestive heart failure. Cardiovasc Res. 2007; 74(1):75-84. [PubMed: 17270161]

175. Lee KW, Everett TH, Rahmutula D, Guerra JM, Wilson E, Ding C, Olgin JE. Pirfenidone Prevents the Development of a Vulnerable Substrate for Atrial Fibrillation in a Canine Model of Heart Failure. Circulation. 2006; 114(16):1703-1712. [PubMed: 17030685] 


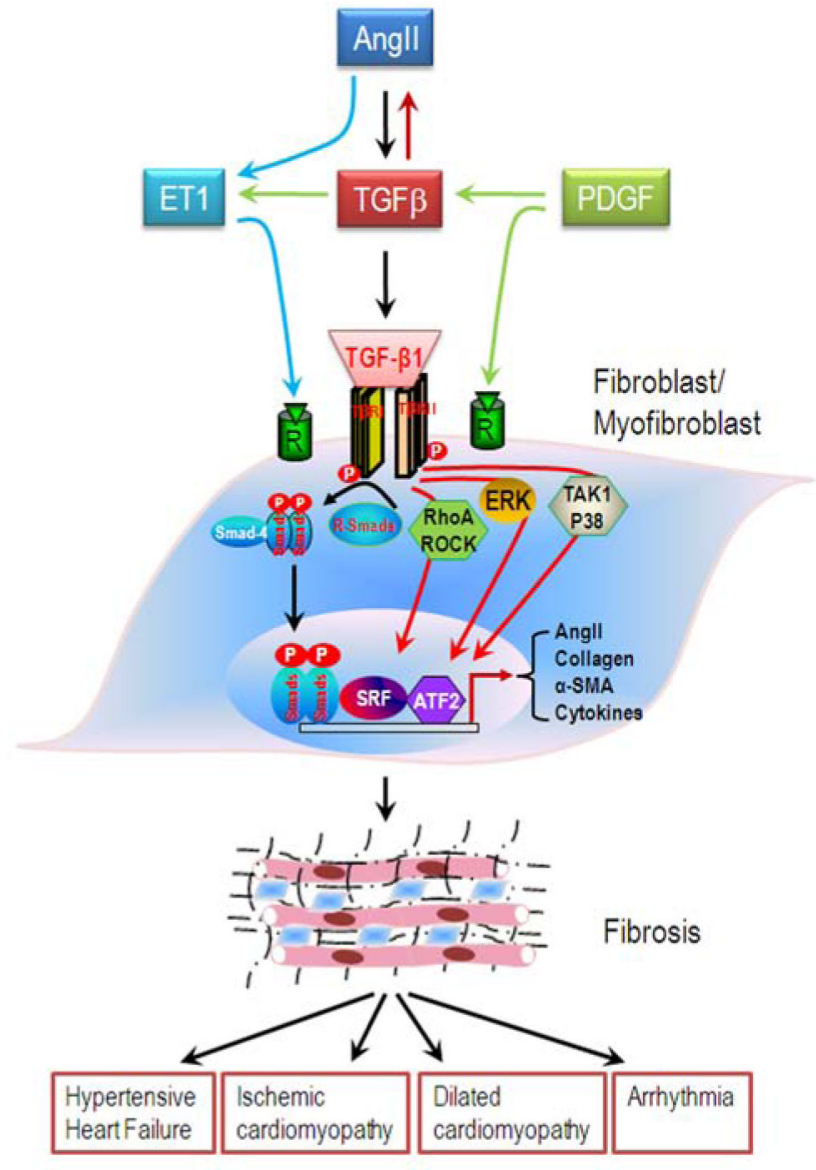

Fig. (1).

Schematic diagram illustrating cardiac fibrogenesis cascade. Multiple signaling pathways and bioactive molecules can activate cardiac fibroblasts, leading to deposition of ECMproteins and formation of fibrosis. Both canonical and noncanonical TGF $\beta$ pathways contribute to fibrogenesis. Cardiac fibrosis is associated with various forms of heart diseases including cardiomyopathy, heart failure, and arrhythmia. 
A

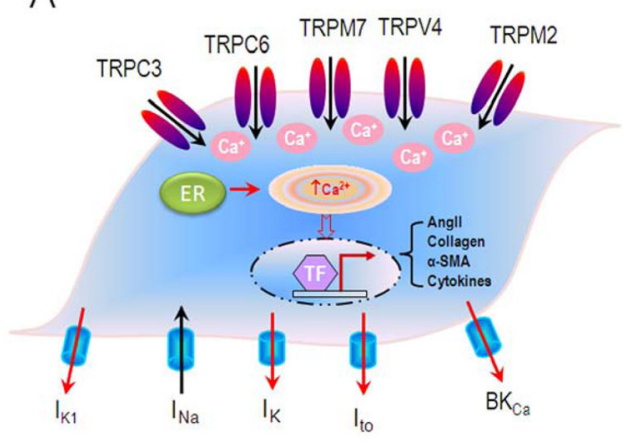

B

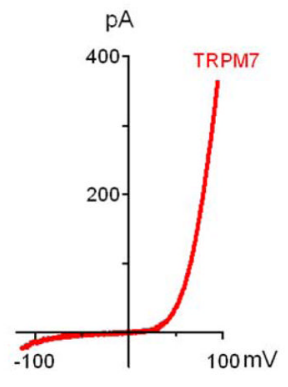

Fig. (2).

Ion channels in the cardiac fibroblasts. A. Summary of ion channels expressed in cardiac fibroblasts. The TRP channel mediated- $\mathrm{Ca}^{2+}$ and $\mathrm{Ca}^{2+}$ released from ER contribute to $\mathrm{Ca}^{2+}$ homeostasis, which regulates fibroblast function under normal and pathological conditions. $\mathrm{Ca}^{2+}$-entry from TRP channels will be largely influenced by the cell membrane potential which is controlled by various $\mathrm{K}^{+}$channel activities. $\mathrm{B}$. A representative recording of TRPM7 from cardiac fibroblasts. 